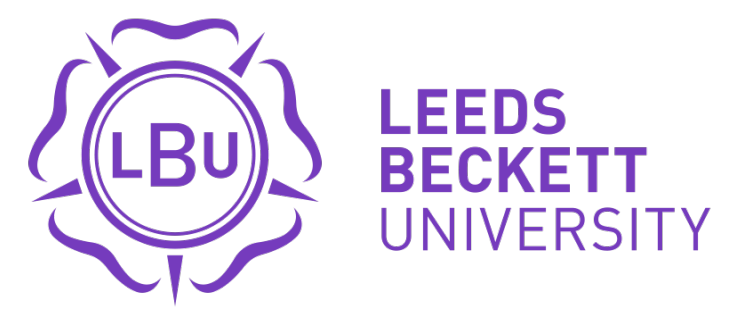

Citation:

Shahbaz, M and Kablan, S and Hammoudeh, S and Nasir, MA and Kontoleon, A (2020) Environmental implications of increased US oil production and liberal growth agenda in post-Paris Agreement era. Journal of Environmental Management, 271. p. 110785. ISSN 0301-4797 DOI: https://doi.org/10.1016/j.jenvman.2020.110785

Link to Leeds Beckett Repository record:

https://eprints.leedsbeckett.ac.uk/id/eprint/6914/

Document Version:

Article (Accepted Version)

Creative Commons: Attribution-Noncommercial-No Derivative Works 4.0

The aim of the Leeds Beckett Repository is to provide open access to our research, as required by funder policies and permitted by publishers and copyright law.

The Leeds Beckett repository holds a wide range of publications, each of which has been checked for copyright and the relevant embargo period has been applied by the Research Services team.

We operate on a standard take-down policy. If you are the author or publisher of an output and you would like it removed from the repository, please contact us and we will investigate on a case-by-case basis.

Each thesis in the repository has been cleared where necessary by the author for third party copyright. If you would like a thesis to be removed from the repository or believe there is an issue with copyright, please contact us on openaccess@leedsbeckett.ac.uk and we will investigate on a case-by-case basis. 


\title{
Environmental Implications of Increased US Oil Production and Liberal Growth Agenda in Post -Paris Agreement Era
}

\author{
Sandrine Kablan \\ ERUDITE, University of Paris Est Creteil, France. \\ Email: sandrine.kablan@u-pec.fr \\ Shawkat Hammoudeh \\ Drexel University, USA \\ Email: shawkat.hammoudeh@gmail.com
}

Muhammad Shahbaz

Beijing Institute of I.T. China, University of Cambridge, United Kingdom

Email: muhdshahbaz77@gmail.com

Muhammad Ali Nasir

Leeds Beckett University, United Kingdom.

Email: M.A.Nasir@leedsbeckett.ac.uk

Andreas Kontoleon

Department of Land Economy, University of Cambridge, United Kingdom

Email: ak219@cam.ac.uk

\begin{abstract}
Contextualising on the internationally low oil price era and historically high oil production in USA and refusal to honour the commitments under Paris Agreement (COP: 21), this study investigates the role of education, oil prices and natural resources abundance on $\mathrm{CO}_{2}$ emissions and energy demand in the USA during 1976-2016. In so doing, we employed a bound testing approach to cointegration which also accounts for the structural breaks. Key findings suggest the presence of a long-run association between underlying variables. The abundance of natural resources and growth of the US economy seems to weigh on environmental quality by increasing energy consumption and carbon emissions. Oil prices showed a negative association with energy consumption as well as emissions suggesting that a low oil price regime can lead to an increase in carbon emissions and energy consumption. Interestingly, education seems to play an important role by reducing energy consumption and carbon emissions, resultantly improving the US environmental quality. Our findings have profound environmental implications in terms of efforts to tackle climate change and meeting the Paris agreement (COP: 21) ambitions with reality and USA policy stance.
\end{abstract}

Keywords: Natural Resources, Oil Prices, Education, Energy and Emissions, COP: 21 JEL Classifications: O13, P18, P48, Q35, Q43, Q57 


\section{Introduction}

The United States is the largest economy and the $2^{\text {nd }}$ major consumer of oil and energy. The size of the US economy and the corresponding magnitude of consumption of natural resources have important economic and ecological implications not only for this largest global economy but also for the rest of the world. The recent statistics suggest that the US consumed 19.631 million barrels of oil per day (MBPD) in 2016, indicating a clear blue water between the US and it's nearest rival China which consumed 12.38 MBPD in the same period (Statista, 2017). On the other side of the energy equation (i.e., production), recent statistics suggest that in 2016, the US produced about 12.354 MBPD, which is more than Saudi Arabia in the same period. This is a sharp increase in oil production in the US, compared to a decade before.

This significant increase in US oil production has potentially important implications not only for global oil production but also for the world's oil consumption and $\mathrm{CO}_{2}$ emissions. The resources abundance defined in terms of increased domestic production implies a positive development in supply where intuitively, a positive supply shock shall bring prices down, and thereby increases oil consumption. In this aspect, the recently coined term "Carbon Curse" by Friedrichs and Inderwildi (2013) suggests that oil-rich countries may prone to have a high intensity of $\mathrm{CO}_{2}$ emissions. However, they argued that some countries with an appropriate policy framework to avoid carbon curse (e.g. Norway). Is it the case for the US, which is in the era of resources (oil) abundance, An empirical study by Balsalobre-Lorente et al. (2018) on the EU-5 suggests a negative impact of natural resources abundance on $\mathrm{CO}_{2}$ emissions implying that an increase in natural resources abundance reduces carbon emissions. Conversely, those authors highlight the importance of regulations on renewable energy, designed to enhance its usage and 
promote energy innovations in order to alleviate the adverse impact of fossil fuel and energy consumption on the environment.

In 2017, the United States withdrew from the Paris Climate Agreement (COP: 21), despite the ratification by large economies and emitters including China and the European Union. In a critical assessment of this accord, Morgan (2016) questions the likelihood of its success based on early trends and nationally determined contributions (NDCs). There will be significant political, economic and ecological ramifications for the US accruing from its withdrawal (Leiserowitz et al. 2016, Saha and Muro 2017, Hultman 2017). Considering the fact that this country has the largest global economy with the largest consumption of energy and is the second-largest $\mathrm{CO}_{2}$ emitter after China, its policies towards climate change should have serious implications and consequences for the whole world. As it stands, the US contributes about $16 \%$ of world emissions. The annual carbon dioxide emissions in tons per capita for the US are 16.1 (Crippa, et al 2019) which are quite high considering its population of over 327 million. The statistics on global $\mathrm{CO}_{2}$ emissions related to energy consumption suggest an increase of over 100\% from 15.51 gigatons in 1975 to 32.1 gigaton in 2016 (IEA, 2017). Concomitantly, this upsurge in global $\mathrm{CO}_{2}$ emissions due to rising energy consumption is a point of great concerns. The surging $\mathrm{CO}_{2}$ emissions levels have exposed the world to the threat of existential challenges in the form of global warming and climate change. Undoubtedly, global warming is predominantly caused by the emissions of Greenhouse Gases (GHGs) due to extensive consumption and dependence on fossil energy sources to fuel economic development (Chiu, 2017).

In addition to the US withdrawal from the Paris Agreement, another important factor we consider in this treatise is the outlook of the global oil market. Prices of oil fell sharply from the 
second quarter of 2014 to the beginning of 2016, a drop of over 70\%. In fact, higher oil prices have contributed to increased oil production in the US (Helman, 2017). The new energy and oil abundance in the US imply that the US economy and oil consumption should not significantly be affected by negative future oil supply shocks as they used to be. On the other hand, the increased production due to supply shocks may further increase consumption of oil with concomitantly severe ecological consequences, particularly when the new administration focuses on infrastructure, job creation and economic growth than on environmental sustainability.

In order to deal with such ecological issues, the one proposed approach is to address these issues by focusing on education. As advocated by the UNESCO, education can play an important part to tackle climate change challenges. Particularly by focusing on the youth and making them comprehend the consequences of global warming (UNESCO, 2017)". In the literature, several authors study the impact of education on the sensitivity of individuals to the environment. Thus, Meyer (2015) studies how educational attainment influences environmental consciousness in Europe. He finds that more education leads individuals to be more concerned with social welfare and have a more eco-friendly attitude. Similarly, Grimaud and Tournemaine (2007) show that environmental policy promotes growth via education. Chankrajang and Muttarak, (2017) show that, the most educated individuals were the most sensitive to environmental issues. Other authors, however, such as Ek and Soderholm (2008), Ayalon et al. (2014), Wessels et al. (1999) find no evidence that a higher level of education encourages pro-environmental behaviours. Besides, despite US government policy orientation, American public opinion seems quite sensitized and educated to climatic problems. Indeed, since 1990 the national environmental education act has been transformed into American law. This act engages the federal 
government's responsibility in environmental education and also emphasizes the need to address the complex challenges of protecting the environment through education of American citizens. This education involves instilling knowledge, skills and motivation to make informed decisions and taking responsible actions to ensure environmental quality, (National Environmental Education Advisory Council, 1996).

Keeping the unprecedented increase in US domestic oil production, the withdrawal from the Paris Agreement, natural resource abundance and the globally low oil prices, we analyse the implications of natural resource abundance (increases in, oil, mineral, coal, forest and natural gas rents), oil prices and education on demand of energy and $\mathrm{CO}_{2}$ emissions from 1976 to 2016 for the US economy. Concomitantly, a bounds-testing approach to cointegration which accounts for the structural breaks is applied to the underlying dataset. The aim is to draw inferences on how the two response variables i.e. energy consumption and $\mathrm{CO}_{2}$ emissions are affected by natural resources abundance, economic growth, oil prices and education.

The objective of this study is twofold. First, it aims to explore the effect of natural resources abundance and relatively low oil prices on energy demand and $\mathrm{CO}_{2}$ emissions within the resources led-energy hypothesis. It examines the resources effect within the U- or inverted-U hypothesis. Second, since UNESCO considers education as an essential element of the global response to climate change, the second objective is to examine how education can mitigate the adverse impact of increasing natural resources production and consumption on $\mathrm{CO}_{2}$ emissions. The key empirical findings suggest the presence of a long-run association between the response and explanatory variables. Natural resource abundance showed a positive effect on the consumption of energy and emissions of $\mathrm{CO}_{2}$. Furthermore, economic growth adds to the usage of energy and environmental degradation. On the positive side, education reduces energy 
intensity and improves environmental quality in the United States. However, oil prices are negatively associated with the consumption of energy and emissions of $\mathrm{CO}_{2}$. Our causality analysis points to a feedback effect between natural resources and emissions of $\mathrm{CO}_{2}$ and hence highlights the resources led-energy hypothesis. $\mathrm{CO}_{2}$ emissions are caused by energy consumption. There is also ample support underlying that the low oil prices regime, as well as an inconsiderate and thoughtless growth agenda and abundance of US domestic oil production, have severe ecological consequences, particularly when considering that the new US administration has shown its resolve to revive coal production and withdraw from the Paris Agreement.

The paper proceeds as follows: Section 2 provides a brief reflection on the existing empirical evidence on the subject and contextualizes the argument put forward by the study. Section 3 discusses the empirical framework and Section 4 present and discuss the findings. The conclusion is drawn in the Section 5 policy implications are discussed.

\section{Withdrawal from Paris Agreement and Underlying Contributory Factors to $\mathrm{CO}_{2}$ Emissions}

In serving the first year in office, President Trump declared that the US is withdrawing from its commitments towards COP-21 and argued against the pledge made by the previous administration that by the year 2025, the United States would cut its emissions 26-28\% below its 2005 levels (Galston 2017, Mooney 2017, Gross 2017, Gross 2017, Hultman 2017).

It does not require a lot to comprehend why the withdrawal of the US has so much significance, not only morally and politically but ecologically. Perhaps, this significance is prima facie evident is manifested in the US share in global energy consumption and carbon emissions. In this scenario, one question arises: what are the significant contributory factors to oil 
consumption and carbon emissions in the contexts of the current outlook of oil market and the US economy? The US oil production is at an all-time high and expected to eclipse the 1970 record in 2018, oil prices are in a relatively low regime and are expected to remain so in the foreseeable future, the U.S. economy has been growing and the U.S. administration has shown an intention to invest in the US infrastructure which garners more future economic growth. Perhaps, these are the factors which can have significant ecological implications, irrespective of the U.S. federal government position on the Paris Agreement (which is non-binding anyway).

Nonetheless, public support and domestic backlash of the withdrawing from the accord also raise the question of what role public awareness and education can play in terms of reducing the detrimental effects of energy consumption and carbon emissions. With this in focus, there are four contributory factors to oil consumption and concomitantly $\mathrm{CO}_{2}$ emissions, which this study has brought into the analysis. We explore the relationship between natural resources abundance, consumption of energy, growth of the economy, oil prices, education and $\mathrm{CO}_{2}$ emissions. Concomitantly, the theme of this study and the related evidence on the subject can be divided into three dimensions or nexuses: (i) the oil price/income-energy consumption-carbon emissions nexus, (ii) the natural resources-energy consumption-carbon emissions nexus, and (iii) the education-energy consumption-carbon emissions nexus. In the following, we will elaborate nexuses further.

\subsection{Oil Price/ Energy Consumption, Income \& Emissions Nexus}

Analogous to the behaviour of any other commodity or a normal product, the price elasticity of demand and consumption of oil should be expected to be negative, particularly, for the consumers. However, given the fact that oil is an important ingredient in the production 
process and an important fraction of households' overall expenditures, there are limits to which the demand for oil may respond to oil shocks. Oil is significantly important for any economy and its importance is paramount for the largest global economy (Kilian, 2008). In a global analysis of oil prices by the IMF's staff, Husain et al. (2015) suggest that the decrease in prices should increase the consumption of oil by the importers and stimulate the supply of sectors of the economy for which oil is an input. In a more recent study, Caldara et al. (2017) found that the positive supply and global demand shocks leading to a decrease in oil prices boosts economic activity in developed countries. This implies that oil price shocks, either due to the supply or demand factors, have important implications for the real economy via consumption and investment. At the same juncture, it raises the questions of how oil consumption itself gets influenced by oil price shocks. In this aspect, based on evidence from the GCC countries, Alam et al. (2016) report that demand for oil is income elastic but price inelastic.

The overall results suggest a positive effect of income and the negative effect of oil prices on oil consumption. On the other hand, Dees et al. (2007), in a comprehensive analysis on a number of countries, report that their policy simulations indicate that oil demand and non-OPEC supply are rather inelastic to changes in oil prices. It employs that the nexus between oil prices and oil consumption may vary country to country, and hence any inference shall be drawn with a pinch of salt. However, this heterogeneity in the response is not idiosyncratic to a country, and even under the analysis, there is mixed evidence for the same country under the analysis. For instance, Bekhet and Yusop (2009) report a negative impact of increased oil prices on its consumption in Malaysia, while in another study on Malaysia, Yusoff and Latif (2013) show that both in the long run as well as short-run, the demand of energy is found to be income elastic and oil price inelastic. Chai et al. (2016) argue that carbon emissions would fall if increases in oil 
prices are linked with the demand for renewable energy, and undoubtedly that inference would also be subject to a country-level heterogeneity. Darrat and Gilley (1996) had given an indication of this mixed evidence before, though they reported a negative impact of the increase in oil prices on the consumption of oil.

Oil, as a major input to the overall process of production, should imply that increased consumption of oil would be seen as a positive contributing factor to the growth of the economy. On this aspect, Arora and Shi (2016) indicate a significant association between growth and consumption of oil. However, that may not always be the case as Hsiao-Ping and Tsangyao (2012) on the USA, report a unidirectional causal relationship from growth to the consumption of oil, but not the other way round. It indicates that economic growth may induce oil consumption, yet oil consumption may not lead to economic growth. Hence, the aggregate demand may increase oil consumption, but oil consumption does not lead to an increase in the output and aggregate demand. In this nexus, where the price shall play an important role, the ecological factors are also a matter of concern.

On this notion, Mosa (1998) reports a positive impact of income and a negative effect of oil prices on the demand of oil, this author reveals that coal exhibits very low elasticity of substitution. Perhaps, even if we compare coal with rather ecologically feasible substitutions, the results are also not very promising. For instance, on the aspect of price substitution an important study by Mazraati and Shelbi (2011) contend that in the context of GHG and ecological issues, there is little to expect that the policy of alternative fuels and alternative fuel vehicles (AFVs) may bring much results, unless sustainable levels of high oil prices are reached. A similar conclusion was reached by Asali (2011) in the analysis of the G-7 and BRIC economies. Perhaps, it may not be the case that price increases could, in fact, reduce oil consumption. Chai 
et al. (2016), analysing the relationship between oil prices, consumption of energy and emissions in China, report that oil prices have a positive impact on consumption of energy and carbon emissions. Hence, it is vital to consider the nexus between income/price and energy consumption/emissions, while considering natural resources abundance and education as a silver lining in this nexus, in specific to a country. The current study is an endeavour in this dimension.

\subsection{Natural Resources-Energy Consumption-Carbon Emissions Nexus}

In parallel to the demand which could be influenced by the price and income (as we discussed in the last paragraph), the supply is a crucial factor in determining the level of oil consumption. On this aspect, Hamilton (2009) provides an interesting discussion on the causes of oil (supply) shocks and compares them with the 2007-2008 oil shock. He argues that one good way to deal with these shocks could have been that, in the spring of 2008 , the government could have sold some oil available in the Strategic Petroleum Reserve (SPR). An interesting point to note here is that during that period, US domestic oil production was significantly lower than its demand, thereby exerting strong pressure on prices and concomitantly having implications for consumption. In a world where the US production has increased more than its average daily requirement, its consumption may not be influenced by supply shocks to the same intensity as it used to be. Perhaps, there could be different implications for the consumer and also the way market views the supply shocks. There is a relevant phenomenon which Killian (2009) called a "precautionary demand" feature that is related to market concerns about the availability of oil supplies in the future. Concomitantly, it is logically plausible to infer that if the US is producing domestically more than its requirements, it will affect consumption positively without the precautionary concerns about the negative global oil supply shock. The relevant and related evidence on this aspect, most prominently, the seminal study by Killian (2008b) suggests that the 
timing, sign as well as the magnitude may vary from the contemporary estimates. Based on the empirical results, Killian (2008b) argued although historically the oil price shocks have profound significance, particularly for the US economy, however, that the exogenous oil supply shocks had made very little difference since the 1970s. Without downplaying the importance of the supply shock, the subject study is intended to see this phenomenon through the channel of domestic supply shocks and their concomitant consumption and ecological implications (Hamilton 2009, Killian 2009, Helman 2017).

The notion that the increase in domestic supply can counter the negative supply shock is intuitive; however, it also suggests that the increase in production will then bring an increase in consumption and related ecological consequences. On this notion, Shearer et al. (2016) show that the abundance of natural gas can lead to higher consumption and greater $\mathrm{CO}_{2}$ emissions as well as a discouragement of renewables use. It led them to suggest that policy interventions are therefore necessary. Perhaps, it might be worst in the case of positive oil supply shocks and the resulting consumption and emissions, which then implies that the policy interventions are even more vital and necessary, though the mood of the US administration does not appear to be ecologically oriented as evident by the withdrawal from the Paris Agreement.

\subsection{Education-Energy Consumption-Carbon Emissions Nexus}

Last but not least, an important factor which influences the consumption of any product is the attitude of the society towards it, which is undoubtedly shaped and influenced by education. It is intuitive to expect that the same may hold true for the consumption of oil and concomitantly for $\mathrm{CO}_{2}$ emissions. On the aspect of education and the environment, is the one notion of ecological driving which has the intention to increase awareness among the users of vehicles by 
implementing Eco-driving, which is an efficient approach to driving emphasizing the efficiency of fuel as well as safety.

The notion of Eco-driving goes as far back as the 1970s (Greene, 1986). Since then, quite a few studies have examined the effectiveness of such a program in a number of countries. A study by Wengraf (2012) compiled the findings of different studies on this aspect which show varying degrees of fuel savings between drivers. One can argue that these programs are effective and useful; however, an important feature of them is that they operate at the micro-level. There are a limited number of drivers which participate in these programs and there are various dimensions in which these programs can be enhanced (see Barić et al. 2013 for discussion) ${ }^{1}$. However, an aspect of equal importance which we would like to emphasise here is the general level of education in society. In a remarkable study on the role of female education and family planning in carbon emissions, within the context of developing countries, Wheeler and Hammer (2010) suggest that the population policy has an important role to play in this regard. They argue that family planning and female education in developing countries are complementary and costeffective tools that lead to mitigating climate change issues. Perhaps, in the context of the Paris agreement (COP21), while appreciating the efforts and commitments to reduce $\mathrm{CO}_{2}$ emissions by global communities and leaders, including the generous promise of at least $\$ 100$ billion per year as a financing target for developing countries, Kharas (2016) argues that a rather basic mechanism which could be more effective has not gained attention. The mechanism is education, in particular, girls' education (Kharas, 2016).

The argument put forward by Kharas (2016) is logical and perhaps even more important as the US has withdrawn from the Paris Agreement (COP21). However, if education can

\footnotetext{
${ }^{1}$ Similarly, the evidence on the investment in human capital and energy consumption is inconclusive and is lacking to shed much light on any reductions in resulting emissions (for instance, contrast Diks and Wolski2015, Ilesanmi and Tiwari 2017, Fang and Wolski 2017).
} 
somehow counter and contribute to the decreased consumption of oil and $\mathrm{CO}_{2}$ emissions, that will then have significant policy implications. To best of our knowledge, there is not much evidence on the nexus between the overall education level and its effects on oil consumption and $\mathrm{CO}_{2}$ emissions. One study which we will acknowledge here is from Bangladesh, where Uddin (2014) highlights the negative impact of education on $\mathrm{CO}_{2}$ emissions. Perhaps, there is one more reason that education relations with oil consumption and carbon emissions should be put-through to analysis, as a study by Sinha et al. (2010) which shows that on average, the operation of higher education institutions in the US had contributed to an equivalent of 52,434 metric tons of annual $\mathrm{CO}_{2}$ emissions. This is indeed a significant contribution to detrimental ecological implications. Yet, an important point to consider is whether education, which is the outcome and the product of educational institutions, then leads to whether falling consumption of oil and $\mathrm{CO}_{2}$ emissions.

\section{Modelling, Data and Methodology}

\subsection{Model Construction}

This treatise examines the effects of natural resources abundance on the consumption of energy and emissions of $\mathrm{CO}_{2}$ by employing energy demand and carbon emissions functions which are by augmented economic growth, oil prices and education as additional determining factors of energy demand and emissions. Growth of an economy entails increased consumption of energy and hence emissions of more carbon via economic activity, while the increase in the price of oil is likely to have substitution effects which can be manifested in the increased the demand for renewables and other forms of fossil fuels, which may provide contrasting empirical findings. On the other side, the increasing oil prices lead the coal demand which generates more emissions compared to oil consumption. Education may affect energy consumption via economic 
development, innovations, development of energy-efficient technology, better living standard, and energy usage awareness for individuals and societies, etc. Education may improve environmental quality by encouraging the use of environment-friendly technology (Inglesi-Lotz and Morales, 2017).

The general form of energy demand and emissions functions is given as follows:

$$
\begin{aligned}
& E C_{t}=f\left(R_{t}, Y_{t}, O_{t}, E_{t}\right) \\
& C_{t}=f\left(R_{t}, E C_{t}, Y_{t}, O_{t}, E_{t}\right)
\end{aligned}
$$

where $E C_{t}, R_{t}, Y_{t}, O_{t}, E_{t}$ and $C_{t}$ represent energy consumption, natural resources, economic growth, oil prices, education and $\mathrm{CO}_{2}$ emissions, respectively. We transform the underlying variables into logarithm as adhering to the log-linear specification is rather more suitable (compared to the linear specification) as it yields more efficient and reliable estimates (Shahbaz and Lean, 2012). The empirical equations of energy demand and carbon emissions functions are modelled as follows:

$$
\begin{aligned}
& \ln E C_{t}=\alpha_{1}+\alpha_{2} \ln R_{t}+\alpha_{3} \ln Y_{t}+\alpha_{4} \ln O_{t}+\alpha_{5} \ln E_{t}+\varepsilon_{i} \\
& \ln C_{t}=\beta_{1}+\beta_{2} \ln R_{t}+\beta_{3} \ln Y_{t}+\beta_{4} \ln O_{t}+\beta_{5} \ln E_{t}+\beta_{6} \ln E C_{t}+\varepsilon_{i}
\end{aligned}
$$

where $\ln , E C_{t}, R_{t}, Y_{t}, O_{t}, E_{t}$ and $C_{t}$ represent natural-log of consumption of energy, natural resources, growth, price of oil, education and $\mathrm{CO}_{2}$ emissions as indicated above. However, except oil prices, the data on all other variables was transformed into per capita. Note $\alpha_{2}\left(\beta_{2}\right)>0$ if natural resources increase energy consumption and stimulate carbon emissions; otherwise, $\alpha_{2}\left(\beta_{2}\right)<0$. If the growth of the economy decreases energy intensity and lowers 
carbon emissions by implementing energy-efficient and environment-friendly technology, then $\alpha_{3}\left(\beta_{3}\right)<0$; otherwise, $\alpha_{3}\left(\beta_{3}\right)>0$.

Impact of the price of oil on the consumption of energy and carbon emissions may be ambiguous. Oil prices may increase (decrease) consumption and concomitantly emissions of $\mathrm{CO}_{2}$ or vice versa, in some cases it depends on a country's net oil export position. If education decreases energy intensity and lowers carbon emissions, then $\alpha_{5}\left(\beta_{5}\right)<0$; otherwise, $\alpha_{5}\left(\beta_{5}\right)>0$. Note if $\beta_{6}>0$, it then indicates that the increase in consumption of energy has a positive impact on carbon emissions; otherwise, $\beta_{6}<0$. We should also emphasize that the squared/quadratic term for natural resources is included in energy demand and emissions functions, depending on whether the association between natural resources and energy consumption/emissions of $\mathrm{CO}_{2}$ is nonlinear (U-shaped or inverted-U). If we assume that initially, natural resources are negatively linked with energy consumption (emissions) but after reaching a maxima/minima or threshold level, energy consumption $\left(\mathrm{CO}_{2}\right.$ emissions $)$ would increase with an increase in natural resources, the relationship is classified as (association between natural resources and energy consumption/emissions is U-shaped). However, if initially, natural resources are positively associated with energy consumption $\left(\mathrm{CO}_{2}\right.$ emissions) and after a threshold, they are negatively associated with energy consumption $\left(\mathrm{CO}_{2}\right.$ emissions $)$, then this association is termed as an inverted-U relationship between natural resources and energy consumption/ $\mathrm{CO}_{2}$ emissions). The nonlinear functional forms of energy demand and carbon emissions functions are modelled in the following specifications:

$$
\ln E C_{t}=\gamma_{1}+\gamma_{2} \ln R_{t}+\gamma_{3} \ln R_{t}^{2}+\gamma_{4} \ln Y_{t}+\gamma_{5} \ln O_{t}+\gamma_{6} \ln E_{t}+\varepsilon_{i}
$$




$$
\ln C_{t}=\lambda_{1}+\lambda_{2} \ln R_{t}+\lambda_{3} \ln R_{t}^{2}+\lambda_{4} \ln Y_{t}+\lambda_{5} \ln O_{t}+\lambda_{6} \ln E_{t}+\lambda_{7} \ln E C_{t}+\varepsilon_{i}
$$

Association between natural resources and energy consumption/ emissions is inverted if

$\gamma_{2}\left(\lambda_{2}\right)>0, \gamma_{3}\left(\lambda_{3}\right)<0$; otherwise, the variables are considered to be associated in an inverted-U shape form if $\gamma_{2}\left(\lambda_{2}\right)<0, \gamma_{3}\left(\lambda_{3}\right)>0$.

\subsection{Data}

The time series spans over 56 years of data from 1976-2016. Data series for real GDP (constant 2005 US\$), energy consumption (kt of oil equivalent) and $\mathrm{CO}_{2}$ emissions (metric tons) were collected from the World Development Indicators (CD-ROM, 2017). The data on education is borrowed from Frank (2017). The data are available at the following link http://www.shsu.edu/eco_mwf/inequality.html, until 2015 and then are extrapolated for the last year. Education is defined as high school and college attainment as a proportion of the state population. The data on oil prices are collected from the Federal Reserve Bank of St. Louis. We used the natural resources which included the composite of oil, coal, mineral, forest and natural gas in the form of natural resources composite. Hence, it is a more inclusive proxy to measure the overall increase in natural resources. The data on total natural resources (constant 2005 US\$) are obtained from the World Development Indicators (CD-ROM, 2017). Except for oil prices, we transformed all the data series into per capita units.

\subsection{ARDL Bounds Testing Approach to Cointegration}

An Autoregressive Distributed Lag (ARDL) bounds testing approach to cointegration is employed to explore the long-run association between response and explanatory variables. This 
approach is based on the seminal work of Pesaran et al. (2001) and has several advantages including, for instance, its appropriateness even when the regressors are integrated at the level $\mathrm{I}(0)$ or $1^{\text {st }}$ difference $\mathrm{I}(1)$. Furthermore, by using a simple linear transformation, a dynamic unrestricted ECM can be derived. Nonetheless, this approach is also very effective for a small sample and without any loss of long-run information while can combine the short-run dynamics with the long-run equilibrium. We can express the Unrestricted Error Correction Model (UECM) in the following form:

$$
\begin{aligned}
\Delta \ln E C_{t} & =\vartheta_{1}+\vartheta_{T} T+\vartheta_{E C} \ln E c_{t-1}+\vartheta_{C} \ln C_{t-1}+\vartheta_{R} \ln R_{t-1}+\left[\vartheta_{R^{2}} \ln R_{t-1}^{2}\right]+\vartheta_{Y} \ln Y_{t-1}+\vartheta_{O} \ln O_{t-1} \\
& +\vartheta_{E} \ln E_{t-1}+\sum_{i=1}^{p} \vartheta_{i} \Delta \ln E C_{t-i}+\sum_{j=0}^{q} \vartheta_{j} \Delta \ln C_{t-j}+\sum_{k=0}^{r} \vartheta_{k} \Delta \ln R_{t-k}+\left[\sum_{p=0}^{r} \vartheta_{p} \Delta \ln R_{t-p}^{2}\right] \\
& +\sum_{l=0}^{s} \vartheta_{l} \Delta \ln Y_{t-l}+\sum_{m=0}^{t} \vartheta_{m} \Delta \ln O_{t-m}+\sum_{n=0}^{u} \vartheta_{n} \Delta \ln E_{t-n}+\mu_{t}
\end{aligned}
$$

$$
\begin{aligned}
\Delta \ln C_{t}= & \alpha_{1}+\alpha_{T} T+\alpha_{E C} \ln E C_{t-1}+\alpha_{C} \ln C_{t-1}+\alpha_{R} \ln R_{t-1}\left[\alpha_{R^{2}} \ln R_{t-1}^{2}\right]+\alpha_{Y} \ln Y_{t-1}+\alpha_{O} \ln O_{t-1} \\
& +\alpha_{E} \ln E_{t-1}+\sum_{i=1}^{p} \alpha_{i} \Delta \ln E C_{t-i}+\sum_{j=0}^{q} \alpha_{j} \Delta \ln C_{t-j}+\sum_{k=0}^{r} \alpha_{k} \Delta \ln R_{t-k}\left[\sum_{p=0}^{r} \alpha_{p} \Delta \ln R_{t-p}^{2}\right] \\
& +\sum_{l=0}^{s} \alpha_{l} \Delta \ln Y_{t-l}+\sum_{m=0}^{t} \alpha_{m} \Delta \ln O_{t-m}+\sum_{n=0}^{t} \alpha_{n} \Delta \ln E_{t-n}+\mu_{t}
\end{aligned}
$$

To decide on the sensitivity of hypothesis to the lag order selection, we used F-statistic developed by Pesaran et al (2001). We chose the Akaike Information Criteria (AIC) and specifically, its minimum value to decide on the number of lags. The Akaike Information Criteria (AIC) was found to be the most suitable owing to its superior properties (Lütkepohl, 2006).The hypothesis of the absence of cointegration among the variables (equation-7 and 8) is, $\left.\left.H_{0}: \alpha_{E C}=\alpha_{R} \mid \alpha_{R^{2}}\right\rfloor=\alpha_{Y}=\alpha_{o}=\alpha_{E}=0, \quad H_{0}: \alpha_{C}=\alpha_{R} \mid \alpha_{R^{2}}\right\rfloor=\alpha_{E C}=\alpha_{Y}=\alpha_{O}=\alpha_{E}=0$ against the alternative of cointegration is, $\left.\left.H_{0}: \alpha_{E C} \neq \alpha_{R} \mid \alpha_{R^{2}}\right] \neq \alpha_{Y} \neq \alpha_{0} \neq \alpha_{E} \neq 0, H_{0}: \alpha_{C} \neq \alpha_{R} \mid \alpha_{R^{2}}\right] \neq \alpha_{E C} \neq \alpha_{Y} \neq \alpha_{O} \neq \alpha_{E} \neq 0$. 
To make decisions about cointegration, in their seminal work, Pesaran et al. (2001) devised upper and lower critical bound (UCB and LCB) asymptotic critical values. In a case where we have all the variables integrated of order I (0), the LCB is used, otherwise, the UCB is employed. The F-statistic we compute is based $\operatorname{on}_{F_{E C}(E C / R, Y, O, E)}$ and $F_{C}(C / R, Y, O, E, E C)$ for the energy demand and carbon emissions functions, respectively. Lastly, we drew on the seminal study by Narayan and Narayan (2005) and used their proposed critical values as they are more appropriate for a small sample.

\subsection{VECM-Granger Causality Test}

Confirmation of cointegration leads us to proceed with the investigation for the causal relationship. In a scenario where there is a unique order of integration among all the underanalysis variables, VECM is the suitable candidate for such an investigation (Granger, 1969). The novelty of this approach is that it accounts for the short run as well as long-run causal association. We can specify the functional form as follows:

$$
\begin{gathered}
(1-L)\left[\begin{array}{l}
\ln E C_{t} \\
\ln R_{t} \\
\ln Y_{t} \\
\ln O_{t} \\
\ln E_{t}
\end{array}\right]=\left[\begin{array}{l}
a_{1} \\
a_{3} \\
a_{4} \\
a_{5} \\
a_{6}
\end{array}\right]+\left[\begin{array}{l}
b_{11 i} b_{12 i} b_{13 i} b_{14 i} b_{15 i} \\
b_{21 i} b_{22 i} b_{23 i} b_{24 i} b_{25 i} \\
b_{31 i} b_{32 i} b_{33 i} b_{43 i} b_{53 i} \\
b_{41 i} b_{42 i} b_{43 i} b_{44 i} b_{45 i} \\
b_{51 i} b_{52 i} b_{53 i} b_{54 i} b_{55 i}
\end{array}\right] \times\left[\begin{array}{l}
\ln E C_{t} \\
\ln R_{t} \\
\ln Y_{t} \\
\ln O_{t} \\
\ln E_{t}
\end{array}\right]+. .+\left[\begin{array}{l}
b_{11 i} b_{12 i} b_{13 i} b_{14 i} b_{15 i} \\
b_{21 i} b_{22 i} b_{23 i} b_{24 i} b_{25 i} \\
b_{31 i} b_{32 i} b_{33 i} b_{43 i} b_{53 i} \\
b_{41 i} b_{42 i} b_{43 i} b_{44 i} b_{45 i} \\
b_{51 i} b_{52 i} b_{53 i} b_{54 i} b_{55 i}
\end{array}\right] \\
\times\left[\begin{array}{l}
\ln E C_{t} \\
\ln R_{t} \\
\ln Y_{t} \\
\ln O_{t} \\
\ln E_{t}
\end{array}\right]+\left[\begin{array}{l}
\alpha \\
\beta \\
\delta \\
\phi \\
\vartheta
\end{array}\right] E C T_{t-1}+\left[\begin{array}{l}
\varepsilon_{1 t} \\
\varepsilon_{2 t} \\
\varepsilon_{3 t} \\
\varepsilon_{4 t} \\
\varepsilon_{5 t}
\end{array}\right]
\end{gathered}
$$




$$
\begin{gathered}
(1-L)\left[\begin{array}{l}
\ln C_{t} \\
\ln R_{t} \\
\ln E C_{t} \\
\ln Y_{t} \\
\ln O_{t} \\
\ln E_{t}
\end{array}\right]=\left[\begin{array}{l}
a_{1} \\
a_{2} \\
a_{3} \\
a_{4} \\
a_{5} \\
a_{6}
\end{array}\right]+\left[\begin{array}{l}
\beta_{11 i} \beta_{12 i} \beta_{13 i} \beta_{14 i} \beta_{15 i} \beta_{16 i} \\
\beta_{21 i} \beta_{22 i} \beta_{23 i} \beta_{24 i} \beta_{25 i} \beta_{26 i} \\
\beta_{31 i} \beta_{32 i} \beta_{33 i} \beta_{43 i} \beta_{53 i} \beta_{36 i} \\
\beta_{41 i} \beta_{42 i} \beta_{43 i} \beta_{44 i} \beta_{45 i} \beta_{46 i} \\
\beta_{51 i} \beta_{52 i} \beta_{53 i} \beta_{54 i} \beta_{55 i} \beta_{56 i} \\
\beta_{61 i} \beta_{62 i} \beta_{63 i} \beta_{64 i} \beta_{65 i} \beta_{66 i}
\end{array}\right] \times\left[\begin{array}{l}
\ln C_{t} \\
\ln R_{t} \\
\ln E C_{t} \\
\ln Y_{t} \\
\ln O_{t} \\
\ln E_{t}
\end{array}\right]+. .+\left[\begin{array}{l}
\beta_{11 i} \beta_{12 i} \beta_{13 i} \beta_{14 i} \beta_{15 i} \beta_{16 i} \\
\beta_{21 i} \beta_{22 i} \beta_{23 i} \beta_{24 i} \beta_{25 i} \beta_{26 i} \\
\beta_{31 i} \beta_{32 i} \beta_{33 i} \beta_{43 i} \beta_{53 i} \beta_{36 i} \\
\beta_{41 i} \beta_{42 i} \beta_{43 i} \beta_{44 i} \beta_{45 i} \beta_{46 i} \\
\beta_{51 i} \beta_{52 i} \beta_{53 i} \beta_{54 i} \beta_{55 i} \beta_{56 i} \\
\beta_{61 i} \beta_{62 i} \beta_{63 i} \beta_{64 i} \beta_{65 i} \beta_{66 i}
\end{array}\right] \\
\times\left[\begin{array}{l}
\ln C_{t} \\
\ln R_{t} \\
\ln E C_{t} \\
\ln Y_{t} \\
\ln O_{t} \\
\ln E_{t}
\end{array}\right]+\left[\begin{array}{l}
\alpha \\
\beta \\
\delta \\
\phi \\
\vartheta \\
\omega
\end{array}\right] E C T_{t-1}+\left[\begin{array}{l}
\varepsilon_{1 t} \\
\varepsilon_{2 t} \\
\varepsilon_{3 t} \\
\varepsilon_{4 t} \\
\varepsilon_{5 t} \\
\varepsilon_{6 t}
\end{array}\right]
\end{gathered}
$$

where, $E C \boldsymbol{M}_{t-1}$ and $(1-L)$ are the lagged error correction term and lag operator. A long-run regression model is employed to capture the errors correction. The presence of a long-run causal relationship is evident by the significant and negative values of $\boldsymbol{E C M}_{t-1}$. Furthermore, the Wald test shows the short-run causality by as the first differences of the series shows statistically significant coefficients. For instance, $B_{12, i} \neq 0 \forall_{i}$ suggests that the consumption of energy is causing natural resources, while energy consumption causes natural resources if $B_{11, i} \neq 0 \forall_{i}$ in Granger sense following equation-9. Moreover, following equation-10, $\beta_{12, i} \neq 0 \forall_{i}$ shows that $\mathrm{CO}_{2}$ emissions are the cause of natural resources and that the emissions cause natural resources if $\beta_{11, i} \neq 0 \forall_{i}$ in the Granger sense.

\section{Empirical Analysis and Discussion}

\subsection{Descriptive Statistics}


We first perform the descriptive statistics and correlation analysis anecdotally. The results presented in Table-1 show that as compared to economic growth and natural resources, oil prices are more volatile which is quite intuitive. However, less volatility is noted in consumption of energy compared to emissions and education reflecting the necessity of the former. The JarqureBera test confirms the normal distribution of time series for all the variables as the null of normality is rejected. This leads us to proceed to do the empirical analysis in a linear framework.

The correlation estimates show that the consumption of energy is positively correlated with emissions of carbon. There was also a positive correlation noted between economic growth, natural resources and $\mathrm{CO}_{2}$ emissions, while education and the prices of oil show a negative correlation with carbon emissions. Moreover, natural resources and economic growth are positively correlated with energy consumption, though a negative correlation exists between oil prices (education) and energy consumption. Economic growth and natural resources are negatively correlated which support the notion of a resource curse. There is also a negative correlation between education and natural resources. However, education is positively linked to the growth of the economy and oil prices, and finally, oil prices and economic growth show a positive correlation.

Table-1: Correlation \& Descriptive Statistics

\begin{tabular}{|l|c|c|c|c|c|c|}
\hline & $\ln E C_{t}$ & $\ln C_{t}$ & $\ln R_{t}$ & $\ln Y_{t}$ & $\ln O_{t}$ & $\ln E_{t}$ \\
\hline Mean & 8.9363 & 2.9440 & 6.2259 & 10.5665 & 3.9544 & 4.8951 \\
\hline Median & 8.9494 & 2.9630 & 6.1493 & 10.5758 & 3.9362 & 4.9236 \\
\hline Maximum & 9.0405 & 3.0898 & 7.4109 & 10.8627 & 4.7468 & 5.0998 \\
\hline Minimum & 8.8180 & 2.7086 & 4.8973 & 10.1361 & 2.8997 & 4.6051 \\
\hline Std. Dev. & 0.0553 & 0.0873 & 0.5291 & 0.2235 & 0.5341 & 0.1433 \\
\hline Skewness & -0.5386 & -1.0029 & -0.0769 & -0.3277 & -0.0147 & -0.5162 \\
\hline Kurtosis & 2.6426 & 3.7602 & 3.3792 & 1.7548 & 1.6968 & 2.2774 \\
\hline Jarque-Bera & 2.2541 & 2.0535 & 0.2932 & 3.4651 & 2.9733 & 2.7794 \\
\hline
\end{tabular}




\begin{tabular}{|l|c|c|c|c|c|c|}
\hline Probability & 0.3239 & 0.3483 & 0.8636 & 0.1768 & 0.2261 & 0.2491 \\
\hline Sum & 375.3286 & 123.650 & 261.4909 & 443.7935 & 166.0879 & 205.5963 \\
\hline Sum Sq. Dev. & 0.1254 & 0.3127 & 11.4818 & 2.0495 & 11.6984 & 0.8423 \\
\hline $\ln E C_{t}$ & 1 & & & & & \\
\hline $\ln C_{t}$ & 0.9584 & 1 & & & & \\
\hline $\ln R_{t}$ & 0.3919 & 0.5379 & 1 & & & \\
\hline $\ln Y_{t}$ & 0.4595 & 0.5340 & -0.4587 & 1 & & \\
\hline $\ln O_{t}$ & -0.5013 & -0.4790 & 0.3940 & 0.1483 & 1 & \\
\hline $\ln E_{t}$ & -0.4869 & -0.6366 & -0.4200 & 0.5076 & 0.1403 & 1 \\
\hline
\end{tabular}

\subsection{Unit Root Tests}

In the next step, we investigate the unit root in the variables. The information on unit-roots of the variables is necessary in order to apply cointegration for determining whether there is a long-run relationship between underlying variables of interest. Concomitantly, Ng-Perron and Augmented Dicky and Fuller (ADF) tests are suitable as they provide efficient and reliable empirical results even when we have short span data. The results presented in Table-2 show that although at the level the variables did show the presence of unit-root. However, at the first difference, all the variables show no issue of unit root and are stationary and hence their unique order of integration is I(1). It is worth acknowledging that Ng-Perron approach does not take into account the issue of structural breaks which can make the null hypothesis weak leading less robust empirical evidence. To overcome this issue, we are applying Kim and Perron (2009) approach and the results also report in Table- 2 which complements the results obtained by following Ng-Perron approach. The break dates are in the years 2007, 1999, 2007, 2003 and 2001 in energy consumption, carbon emissions, natural resources, economic growth, prices of oil and education. These dates represent crises, recessions and wars which are consistent with breaks. This presence of the structural breaks in emissions and energy consumption is an indication of the need for 
energy as well as environmental policies for improving environmental quality and sustaining economic development. For example, the regulations and policies of US federal government including the Environmental Policy Act 2005, the ARRA 2009 (Energy Efficiency and Renewable Energy Research and Investment section) and the Energy Independence and Security Act (EISA 2007). Nonetheless, the GFC and the Great Recession were also a contributing factor, though the effects of the policies are clearly evident in having a fruitful result. Total $\mathrm{CO}_{2}$ emissions in the US has been decreasing since its highest point in 2007 (6023 million metric tons, also see Miller, 2013 for an interesting discussion). All the underlying variables are found to be stationary after the $1^{\text {st }}$ difference. It suggests that consumption of energy, emissions, natural resources, growth, prices of oil and education are integrated at I(1).

Table-2: Unit Root Analysis

\begin{tabular}{|l|c|c|c|c|}
\hline \multirow{2}{*}{ Variable } & \multicolumn{4}{|c|}{ Ng-Perron Test } \\
\cline { 2 - 5 } & MZa & MZt & MSB & MPT \\
\hline $\ln E C_{t}$ & $-4.5630(1)$ & -1.3753 & 0.3014 & 18.9762 \\
\hline $\ln C_{t}$ & $-2.3862(3)$ & -0.8075 & 0.3384 & 27.2898 \\
\hline $\ln R_{t}$ & $-10.3470(2)$ & -2.1406 & 0.2068 & 9.4179 \\
\hline $\ln Y_{t}$ & $-7.7304(1)$ & -1.8148 & 0.2347 & 12.1377 \\
\hline $\ln O_{t}$ & $-4.1261(3)$ & -1.3928 & 0.3375 & 21.6115 \\
\hline $\ln E_{t}$ & $-1.1556(2)$ & -0.6090 & 0.5270 & 55.6874 \\
\hline Variable & \multicolumn{2}{|c|}{ ADF in Levels } & & ADF in 1st Diff. \\
\cline { 2 - 5 } & Test-stat. & Year of Break & Test-stat. & Year of Break \\
\hline $\ln E C_{t}$ & $-3.5508(1)$ & 2007 & $-5.1089(2)^{* *}$ & 2008 \\
\hline $\ln C_{t}$ & $-2.4440(2)$ & 2007 & $-4.9303(3)^{* *}$ & 1988 \\
\hline $\ln R_{t}$ & $-3.4758(1)$ & 1999 & $-7.6485(2)^{*}$ & 2000 \\
\hline $\ln Y_{t}$ & $-4.1215(3)$ & 2007 & $-5.2136(1)^{* *}$ & 2009 \\
\hline $\ln O_{t}$ & $-3.2173(2)$ & 2003 & $-7.4784(3)^{*}$ & 1998 \\
\hline $\ln E_{t}$ & $3.4070(3)$ & 2001 & $-6.5579(2)^{*}$ & 2000 \\
\hline
\end{tabular}


Note: $* *$ and $*$ are statistically significant at 5 and $1 \%$ levels. Values in parenthesis show optimal lag length

\subsection{ARDL Cointegration Test}

The bounds testing approach to cointegration can be applied after our variable assured the unique order of integration. The VAR framework is used to choose to optimal lag length and to compute the ARDL F-statistic. Using the optimal lag length of the variables provides a reliable and consistent ARDL F-statistic and vice versa (Shahbaz et al. 2017). This issue of choosing the appropriate lag length is solved by the Akaike information criterion (AIC) which provides efficient empirical evidence regarding the lag order selection due to its strong explanatory power (Liew, 2004). The results are given in Table- 3 based on the AIC (see the $2^{\text {nd }}$ Column). The ARDL F-statistic varies at various lags.

Table-3 (the $4^{\text {th }}$ Column) presents the ARDL bounds testing results and the ARDL Fstatistics for carbon emissions and energy demand functions are calculated separately. In the energy demand function, it showed that F-statistic of ARDL exceeds the upper critical bounds (at $1 \%$ and 5\% levels) as we used energy consumption and education as the dependent variables. Thus we can reject the null hypothesis of no cointegration. However, null is accepted when we used oil prices, natural resources, economic growth as response variables. The empirical results reveal the presence of cointegration ${ }^{2}$. For emissions function, while treating emissions, natural resources and education as a response variable, F-stats exceeded the critical values at $1 \%$ significance level. Concomitantly, we reject the null hypothesis of no cointegration.

Empirical results indicate that for energy demand function, estimates are significant at 99\% confidence level and abundance of natural resources is positively associated with energy

\footnotetext{
2 The empirical findings are similar when we used the squared term of resources in the emissions and energy demand functions and results can be obtained upon request.
} 
consumption. All else equal, it suggests that an increase of $0.37 \%$ in the consumption of energy can result from a $1 \%$ increase in the abundance of natural resource (rents). Our findings are in line with a study on the Malaysian economy by Badeeb et al. (2016) which suggested that oil rents influence economic activity which also increases the demand for energy. Furthermore, the association between energy consumption and economic growth of the economy in our study is also found to be positive and statistically significant supporting this nexus. Ceteris paribus, it showed that an increase of $0.58 \%$ in the consumption of energy is caused by a $1 \%$ increase in economic growth. The results are in line with the study by Shahbaz and Lean (2012), PabloRomero and Jesus (2016), Shahbaz et al. (2016) and Mahalik et al. (2017) which showed that the growth of economy leads to higher consumption of energy in Tunisia, Caribean Region, India and Saudi Arabia.

Our findings on oil prices show that negative association consumption of energy. Specifically, it showed that the energy demand would be reduced by $0.0628 \%$, in response to a $1 \%$ increase in the price of oil. Our findings are in line with those of Jamil and Ahmad (2010) and Shahbaz et al. (2017) who reported a reduction in the consumption of energy due to the increase in oil prices in Pakistan and a panel of 157 countries. Further, the association between education and consumption of energy is found to be negative and statistically significant. Ceteris paribus, it implies that a $1 \%$ increase in education reduces energy consumption by $0.2371 \%$. This result reflects the importance of education in dealing with climate change. This finding adds to inconclusive evidence in the literature and substantially add to the studies by Salim et al. (2017) and Fang and Wolski (2017) who consider the effects of human capital on the consumption of energy and report negative to neutral effects in China. 
In order to investigate whether a nonlinear (inverted-U or U-shape) association exists between an abundance of natural resources and energy consumption; we have included a quadratic term for natural resource. It showed that there is a U-shaped association between the abundance of natural resources and consumption of energy. Specifically, there natural resource abundance shows a negative association with consumption of energy in the beginning, however, after reaching a threshold it starts to increase the consumption of energy. Overall, energy demand function with linear and nonlinear terms of natural resources is statistically significant. It showed no issue of serial correlation. The energy demand function is well explained by growth of economy, abundance of natural resources, price of oil and education. The diagnostic analysis underlines the normally distributed residual and no issue of serial correlation, ARCH and white heteroscedasticity. The Ramsey regression equation specification error test (RESET) showed that the model is well specified. 
Table-3: ARDL Cointegration Analysis

\begin{tabular}{|c|c|c|c|c|c|c|c|c|c|}
\hline \multicolumn{4}{|c|}{ Bound-testing } & \multicolumn{6}{|c|}{ Diagnostic } \\
\hline Models & Lags & Year of Break & F-stat. & Normality & ARCH & RESET & SERIAL & CUSUM & CSUSUM $^{2}$ \\
\hline \multicolumn{10}{|c|}{ Energy Demand Function } \\
\hline$E C_{t}=f\left(R_{t}, Y_{t}, O_{t}, E_{t}\right)$ & $2,2,1,2,2$ & 2007 & $9.150 *$ & 0.7161 & 1.8005 & 2.6501 & 0.9101 & Stable & Stable \\
\hline$R_{t}=f\left(E C_{t}, Y_{t}, O_{t}, E_{t}\right)$ & $2,2,1,1,2$ & 1999 & 4.181 & 0.6112 & 2.1001 & 0.4009 & 1.1106 & Stable & Stable \\
\hline$Y_{t}=f\left(E C_{t}, R_{t}, O_{t}, E_{t}\right)$ & $2,2,1,2,2$ & 2007 & 3.106 & 0.1513 & 1.6081 & 1.1006 & 2.1132 & Stable & Stable \\
\hline$O_{t}=f\left(E C_{t}, R_{t}, Y_{t}, E_{t}\right)$ & $2,2,1,1,2$ & 2003 & 4.151 & 2.1516 & 2.1001 & 0.3061 & 0.1302 & Stable & Stable \\
\hline$E_{t}=f\left(E C_{t}, R_{t}, Y_{t}, O_{t}\right)$ & $2,2,1,1,2$ & 2001 & $9.879 *$ & 1.3210 & 4.1027 & 2.1021 & 0.3043 & Stable & Stable \\
\hline$E C_{t}=f\left(R_{t}, R_{t}^{2}, Y_{t}, O_{t}, E_{t}\right)$ & $2,2,1,2,2,2$ & 2007 & $10.111^{*}$ & 1.2123 & 2.2002 & 2.1001 & 0.3104 & Stable & Stable \\
\hline$R_{t}, R_{t}^{2}=f\left(E C_{t}, Y_{t}, O_{t}, E_{t}\right)$ & $2,2,1,1,2,1$ & 1999 & 4.150 & 0.7515 & 1.8080 & 2.3012 & 0.9021 & Stable & Stable \\
\hline$Y_{t}=f\left(E C_{t}, R_{t}, R_{t}^{2}, O_{t}, E_{t}\right)$ & $2,2,1,2,2,2$ & 1999 & 5.510 & 0.7161 & 2.0298 & 1.9007 & 1.8130 & Stable & Stable \\
\hline$O_{t}=f\left(E C_{t}, R_{t}, R_{t}^{2}, Y_{t}, E_{t}\right)$ & $2,2,1,1,2,1$ & 2003 & 3.018 & 0.6170 & 2.3201 & 0.4030 & 1.1010 & Stable & Stable \\
\hline$E_{t}=f\left(E C_{t}, R_{t}, R_{t}^{2}, Y_{t}, O_{t}\right)$ & $2,2,1,1,2,2$ & 2008 & $8.784^{*}$ & 0.1651 & 1.7262 & 1.3008 & 2.1311 & Stable & Stable \\
\hline \multicolumn{10}{|c|}{ Carbon Emissions Function } \\
\hline$C_{t}=f\left(R_{t}, Y_{t}, O_{t}, E_{t}, E C_{t}\right)$ & $2,2,2,2,2,2$ & 2007 & $9.100^{*}$ & 0.7060 & 1.8115 & 2.6231 & 0.9131 & Stable & Stable \\
\hline$R_{t}=f\left(C_{t}, Y_{t}, O_{t}, E_{t}, E C_{t}\right)$ & $2,2,2,1,2,2$ & 1999 & $10.118^{*}$ & 0.6110 & 2.1011 & 0.4319 & 1.1316 & Stable & Stable \\
\hline$Y_{t}=f\left(C_{t}, R_{t}, O_{t}, E_{t}, E C_{t}\right)$ & $2,2,1,2,2,2$ & 2007 & 3.116 & 0.1503 & 1.6181 & 1.1036 & 2.1332 & Stable & Stable \\
\hline$O_{t}=f\left(C_{t}, R_{t}, Y_{t}, E_{t}, E C_{t}\right)$ & $2,2,2,1,2,2$ & 2003 & 4.101 & 2.1506 & 2.1011 & 0.3361 & 0.1332 & Stable & Stable \\
\hline$E_{t}=f\left(C_{t}, R_{t}, Y_{t}, O_{t}, E C_{t}\right)$ & $2,2,1,2,2,2$ & 2001 & 4.079 & 1.3010 & 4.1127 & 2.1033 & 0.3143 & Stable & Stable \\
\hline$E C_{t}=f\left(C_{t}, R_{t}, Y_{t}, O_{t}, E_{t}\right)$ & $2,2,2,2,2,2$ & 2007 & $9.178^{*}$ & 1.2023 & 2.2112 & 2.1021 & 0.3114 & Stable & Stable \\
\hline$C_{t}=f\left(R_{t}, R_{t}^{2}, Y_{t}, O_{t}, E_{t}, E C_{t}\right)$ & $2,2,2,2,2,2,2$ & 2007 & $9.108^{*}$ & 0.7010 & 1.8081 & 2.3212 & 0.9225 & Stable & Stable \\
\hline
\end{tabular}




\begin{tabular}{|c|c|c|c|c|c|c|c|c|c|}
\hline$R_{t}, R_{t}^{2}=f\left(C_{t}, Y_{t}, O_{t}, E_{t}, E C_{t}\right)$ & $2,2,2,1,2,2,1$ & 1999 & $9.023 *$ & 0.7001 & 2.0218 & 1.9027 & 1.8232 & Stable & Stable \\
\hline$Y_{t}=f\left(C_{t}, R_{t}, R_{t}^{2}, O_{t}, E_{t}, E C_{t}\right)$ & $2,2,1,2,2,2,2$ & 2007 & 4.100 & 0.6071 & 2.3101 & 0.4022 & 1.1412 & Stable & Stable \\
\hline$O_{t}=f\left(C_{t}, R_{t}, R_{t}^{2}, Y_{t}, E_{t}, E C_{t}\right)$ & $2,2,2,1,2,2,2$ & 2003 & 3.959 & 0.1050 & 1.7162 & 1.3128 & 2.1341 & Stable & Stable \\
\hline$E_{t}=f\left(C_{t}, R_{t}, R_{t}^{2}, Y_{t}, O_{t}, E C_{t}\right)$ & $2,2,1,2,2,2,2$ & 2001 & 4.109 & 0.6071 & 2.3211 & 0.4131 & 1.1234 & Stable & Stable \\
\hline$E C_{t}=f\left(C_{t}, R_{t}, R_{t}^{2}, Y_{t}, O_{t}, E_{t}\right)$ & $2,2,2,2,2,2,2$ & 2007 & $9.006 *$ & 0.1511 & 1.7161 & 1.3118 & 2.1301 & Stable & Stable \\
\hline \multirow{2}{*}{ Significance Levels } & \multicolumn{2}{|c|}{ UB- Critical values $(T=42)$} & & & & & & & \\
\hline & At $I(0)$ & At $I(1)$ & & & & & & & \\
\hline $1 \%$ & 7.317 & 8.700 & & & & & & & \\
\hline $5 \%$ & 5.360 & 6.373 & & & & & & & \\
\hline $10 \%$ & 4.437 & 5.377 & & & & & & & \\
\hline
\end{tabular}


Table-4: Long- Run Relationship Analysis

\begin{tabular}{|c|c|c|c|c|c|c|c|c|}
\hline \multirow[t]{2}{*}{ Variables } & \multicolumn{4}{|c|}{ Energy Demand Function } & \multicolumn{4}{|c|}{ Carbon Emissions Function } \\
\hline & Coefficient & T. Statistic & Coefficient & T. Statistic & Coefficient & T. Statistic & Coefficient & T. Statistic \\
\hline Constant & $7.5951^{*}$ & 33.1891 & $8.1526^{*}$ & 39.8623 & $-4.3312^{*}$ & -6.1016 & -5.111866 & -5.0851 \\
\hline $\ln R_{t}$ & $0.3714^{*}$ & 3.9730 & $-0.2117^{*}$ & -2.9457 & $0.5050^{*}$ & 8.8330 & $-0.1007 * *$ & 2.5087 \\
\hline $\ln R_{t}^{2}$ & $\ldots$. & $\ldots$. & $0.0409 *$ & 5.7895 & $\ldots$. & $\ldots$. & $0.0397 *$ & 5.7393 \\
\hline $\ln Y_{t}$ & $0.5785^{*}$ & 9.5380 & $0.5620^{*}$ & 11.6190 & $0.1328 * *$ & 2.1127 & $0.1477^{*}$ & 3.0137 \\
\hline $\ln O_{t}$ & $-0.0628^{*}$ & -5.9750 & $-0.0652 *$ & -7.5998 & $-0.0529 *$ & -6.4719 & $-0.0512 *$ & -5.1082 \\
\hline $\ln E_{t}$ & $-0.2371 *$ & -9.2351 & $-0.2604 *$ & -11.8997 & $-0.3161 *$ & -2.9673 & $-0.1971 * *$ & -2.4452 \\
\hline $\ln E C_{t}$ & .... & $\ldots$. & $\ldots$. & $\ldots$ & $0.8152 *$ & 8.8646 & $0.9156^{*}$ & 7.5052 \\
\hline$D_{t}$ & -0.0096 & -0.6932 & -0.0027 & -0.2482 & 0.0015 & 0.2025 & 0.0014 & 0.1789 \\
\hline$R^{2}$ & 0.9150 & & 0.9519 & & 0.9659 & & 0.9703 & \\
\hline $\operatorname{Adj}-R^{2}$ & 0.9031 & & 0.9435 & & 0.9567 & & 0.9627 & \\
\hline -Statistic & $77.5057^{*}$ & & $78.3052 *$ & & $39.8234 *$ & & 37.7869 & \\
\hline Purbin Watson & 1.7540 & & 1.7906 & & 2.1418 & & 2.0987 & \\
\hline \multicolumn{9}{|l|}{ Stability Test } \\
\hline & F. Stat. & P-value & F. Stat. & P-value & F. Stat. & P-value & F. Stat. & P-value \\
\hline$\chi_{\text {Nomal }}^{2}$ & 1.2520 & 0.4363 & 1.0255 & 0.6507 & 1.2320 & 0.4403 & 1.2055 & 0.4407 \\
\hline$x_{\text {serat }}^{2}$ & 1.6440 & 0.1425 & 1.3227 & 0.2010 & 1.5404 & 0.1500 & 1.2202 & 0.1919 \\
\hline$\chi_{A R C H}^{2}$ & 1.2906 & 0.1351 & 1.2828 & 0.1220 & 1.30176 & 0.1261 & 1.7828 & 0.1125 \\
\hline$F_{\text {Hutuon }}^{2}$ & 1.4177 & 0.9500 & 1.6767 & 0.8520 & 1.6077 & 0.9409 & 1.6075 & 0.8920 \\
\hline$\chi_{\text {Remsay }}^{2}$ & 0.7838 & 0.4017 & 1.2208 & 0.3216 & 1.0838 & 0.3901 & 1.2118 & 0.3015 \\
\hline CUSUM & Stable & & Stable & & Stable & & Stable & \\
\hline CUSUM & Stable & & Stable & & Stable & & Stable & \\
\hline
\end{tabular}

In carbon emissions function, we note a positive association between abundance of natural resources and $\mathrm{CO}_{2}$ emissions. It shows that the abundance of natural resources adds to carbon emissions significantly. Ceteris paribus, $0.50 \%$ increase in the emissions of $\mathrm{CO}_{2}$ can be as 
a result of $1 \%$ increase in the abundance of natural resources. The finding is contrary to that of Shearer et al. (2014) who used natural gas resources as an indicator of natural resource abundance and find that its (such as gas supply) reduce emissions due to the adoption of energyefficient technology in the US economy. The reason for this conflict is obvious as we have employed a more inclusive approach to natural resources which also include oil and coal, and hence gives deeper insight into the implications of energy resource abundance for the U.S. The nexus between economic growth and emissions of carbon is found to be positive and statistically significant. Ceteris paribus, it suggests there could be an increase of $0.1328 \%$ in the emissions due $1 \%$ increase in economic growth. This finding adds to the results reported by Dogan and Turkekul (2015), Soytas et al. (2007) and Menyah and Wolde-Rufael (2010) who respectively report a positive, neutral and feedback effect between the growth of economy and carbon emissions.

The impact of an increase in the price of oil on emissions is found to be negative and statistically significant, suggesting that an increasing price leads to the improvement of environmental quality. Ceteris paribus, $\mathrm{CO}_{2}$ emissions are reduced by $0.0529 \%$ in a response to a $1 \%$ increase in the price of oil. This empirical evidence is at odds with the study on China by Chai et al. (2016) which reported that due to the positive association between price of oil and emissions, the increase in the price of oil leads to increasing emissions and hence degrading environment. In the case of the US, an increase in the price of oil actually has a negative effect which then implies the current fall in those prices could, unfortunately, lead to a surge in $\mathrm{CO}_{2}$ emissions. Education turned out to be ecologically beneficial as it shows that a rise in education lowers emissions and improves environmental quality. These results inline Uddin (2014) as this author finds a negative association between education and carbon emissions in Bangladesh. 
Especially, the coefficient associated to education is relatively important as compared to those of natural resources abundance and oil prices, which implies the significant role that education can play in counter-balancing $\mathrm{CO}_{2}$ emissions and energy consumption. The association between the emissions of $\mathrm{CO}_{2}$ and consumption of energy turned out to be positive which of course hardly surprising. The quadratic term included measuring the nonlinear nexus showed the presence of a U-shaped relation. It suggests that initially the abundance of natural resources has a negative impact on emissions however after a certain minimum they start contributing to increased emissions. Our dummy variable i.e. representing the Energy Independence and Security Act (EISA, 2007), has a negative but insignificant effect on consumption of energy emissions of $\mathrm{CO}_{2}$. This shows that the implementation of EISA, 2007 had some fruitful effects in the US but this result is not very significant.

Overall, the carbon emissions functions are statistically significant and the set of explanatory variables on hand adequately explain them ( $\mathrm{R}^{2}$ with high value confirms it). An absence of autocorrelation between the residual and the variables is prima face evident by the Durban Watson statistics. Diagnostic testing shows a normal distribution of the residual term with no sign of any serial correlation issue. We find no evidence of ARCH and white heteroscedasticity. The Ramsey RESET test supports the notion that the functional form of carbon emissions function is well specified. This underlines the reliability and consistency of the long-run estimates for energy demand as well as emissions functions.

\subsection{Short-run Analysis}

The results of the short-run analysis of energy demand and carbon emissions functions are summarised in Table-5 which complement the above-discussed findings. In energy demand 
function, natural resources are positively and significantly associated with the consumption of energy. The nonlinear association between natural resources and consumption of energy is Ushaped but statistically insignificant. Growth of economy leads to the increasing demand for energy, while oil prices and education reduce energy consumption. In carbon emissions function, we note that natural resources add to $\mathrm{CO}_{2}$ emissions. There was also an insignificant U-shaped relationship found between natural resources and emissions. The growth of the economy also found to have a positive effect on emissions although the results lacked statistical significance. On the other hand, the prices of oil did show a negative and also statistically significant impact. Further, education significantly reduces the consumption of energy, while the consumption of energy itself contributes to emissions of carbon. The coefficient is even greater in absolute value than the long-run coefficient in energy function, indicating a strong recall force. This shows the important role of education in the process of containing energy consumption. The impact of the dummy variable on energy consumption and emissions is although negative but lacked statistical significance.

Table-5: Short Run Analysis

\begin{tabular}{|l|c|c|c|c|c|c|c|c|}
\hline \multirow{2}{*}{ Variables } & \multicolumn{4}{|c|}{ Energy Demand Function } & \multicolumn{4}{c|}{ Carbon Emissions Function } \\
\cline { 2 - 9 } & Coefficients & T. Stat. & Coefficients & T. Stat. & Coefficients & T. Stat. & Coefficients & T. Stat. \\
\hline Constant & $-0.0082^{* * *}$ & -1.8091 & -0.004403 & -0.8812 & -0.0025 & -0.6975 & -0.0031 & -0.8335 \\
\hline$\Delta \ln R_{t}$ & $0.0274^{*}$ & 2.9541 & -0.04168 & 0.6570 & $0.0292^{*}$ & 2.8470 & $-0.0303^{*}$ & 2.8767 \\
\hline$\Delta \ln R_{t}^{2}$ & $\ldots$. & $\ldots$. & 0.025482 & 1.5118 & $\ldots$ & $\ldots$. & 0.0050 & 0.5781 \\
\hline$\Delta \ln Y_{t}$ & $0.7356^{*}$ & 6.4429 & $0.6699^{*}$ & 5.643131 & 0.0708 & 0.5876 & 0.0668 & 0.5482 \\
\hline$\Delta \ln O_{t}$ & $-0.0258^{* * *}$ & -1.9739 & $-0.0177^{* *}$ & -2.0380 & $-0.0224^{* *}$ & -2.1958 & $-0.0231^{* *}$ & -2.0989 \\
\hline$\Delta \ln E_{t}$ & $-0.5139^{* *}$ & -2.4039 & $-0.6776^{*}$ & -3.0924 & -0.0726 & -0.4370 & -0.0438 & -0.2504 \\
\hline$\Delta \ln E C_{t}$ & $\ldots$. & $\ldots$. & $\ldots .$. & $\ldots$. & $0.8638^{*}$ & 8.8776 & $0.8817^{*}$ & 8.5544 \\
\hline$D_{t}$ & -0.0004 & -0.1025 & 0.0020 & 0.4395 & -0.0037 & -0.9767 & -0.0042 & -1.0651 \\
\hline$E C M_{t-1}$ & $-0.6118^{*}$ & -5.1241 & $-0.2930^{* *}$ & -2.9738 & $-0.7389^{*}$ & -3.0838 & $-0.6966^{*}$ & -2.7546 \\
\hline
\end{tabular}




\begin{tabular}{|c|c|c|c|c|c|c|c|c|}
\hline$R^{2}$ & 0.8044 & & 0.7890 & & 0.9128 & & 0.9137 & \\
\hline Adj- $R^{2}$ & 0.7699 & & 0.7429 & & 0.8943 & & 0.8921 & \\
\hline -Statistic & $23.3101^{*}$ & & 17.1031* & & 9.3906* & & $8.8989^{*}$ & \\
\hline Purbin Watson & 1.6407 & & 2.0587 & & 2.1548 & & 2.1764 & \\
\hline \multicolumn{9}{|l|}{ Stability Test } \\
\hline & F. Stat. & P-Value & F. Stat. & P-Value & F. Stat. & P-Value & F. Stat. & P-Value \\
\hline$\chi_{\text {Normal }}^{2}$ & 1.3523 & 0.4213 & 1.2057 & 0.6587 & 1.4325 & 0.4313 & 1.2515 & 0.4247 \\
\hline$\chi_{\text {serial }}^{2}$ & 1.6545 & 0.1385 & 1.4020 & 0.1901 & 1.4505 & 0.1586 & 1.4204 & 0.1710 \\
\hline$\chi_{A R C H}^{2}$ & 1.2607 & 0.1367 & 1.6980 & 0.1125 & 1.3767 & 0.1201 & 1.8787 & 0.1065 \\
\hline $\bar{K}_{\text {Hereon }}^{2}$ & 1.4707 & 0.8908 & 1.5570 & 0.8627 & 1.6707 & 0.9319 & 1.6705 & 0.9318 \\
\hline$\chi_{\text {Remsay }}^{2}$ & 0.8803 & 0.3907 & 1.8230 & 0.1121 & 1.8038 & 0.1201 & 1.2801 & 0.2919 \\
\hline CUSUM & Stable & & Stable & & Stable & & Stable & \\
\hline CUSUM & Stable & & Stable & & Stable & & Unstable & \\
\hline
\end{tabular}

Further, the estimates of $E C M_{t-1}$ for the energy demand function and carbon emissions function are negative as well as statistically significant at $1 \%$ and $5 \%$ levels, respectively. The statistical significance of the estimates of $E C M_{t-1}$ depicts the pace of adjustment towards the long-run equilibrium path from the short-run. The values of $E C M_{t-1}$ are -0.6118 and -0.7389 for the energy demand and carbon emission functions, respectively. This shows a speed of adjustment of $61.18 \%$ and $73.89 \%$ for both. The energy demand and carbon emission functions fulfil all the underlying assumptions of the classical linear regression model (CLRM). The Jarque-Brea test statistic shows that the error terms for energy demand and carbon emissions functions are normally distributed with no serial correlation and ARCH issue. The Ramsey RESET test confirms the absence of misspecification problem for those functions. 


\subsection{Reliability Tests}

To assess the reliability of acquired estimates of short run and long-run relationships, we also perform the CUSUM and CUSUMsq tests (See Pesaran and Shin, 1999 for details). The null hypothesis suggests that a well-specified functional form of the empirical model can be rejected if the plots exceed the critical bounds. The results are shown in Figure- 2 and 3 for energy demand and carbon emissions functions, respectively.

\section{Energy Demand Function}

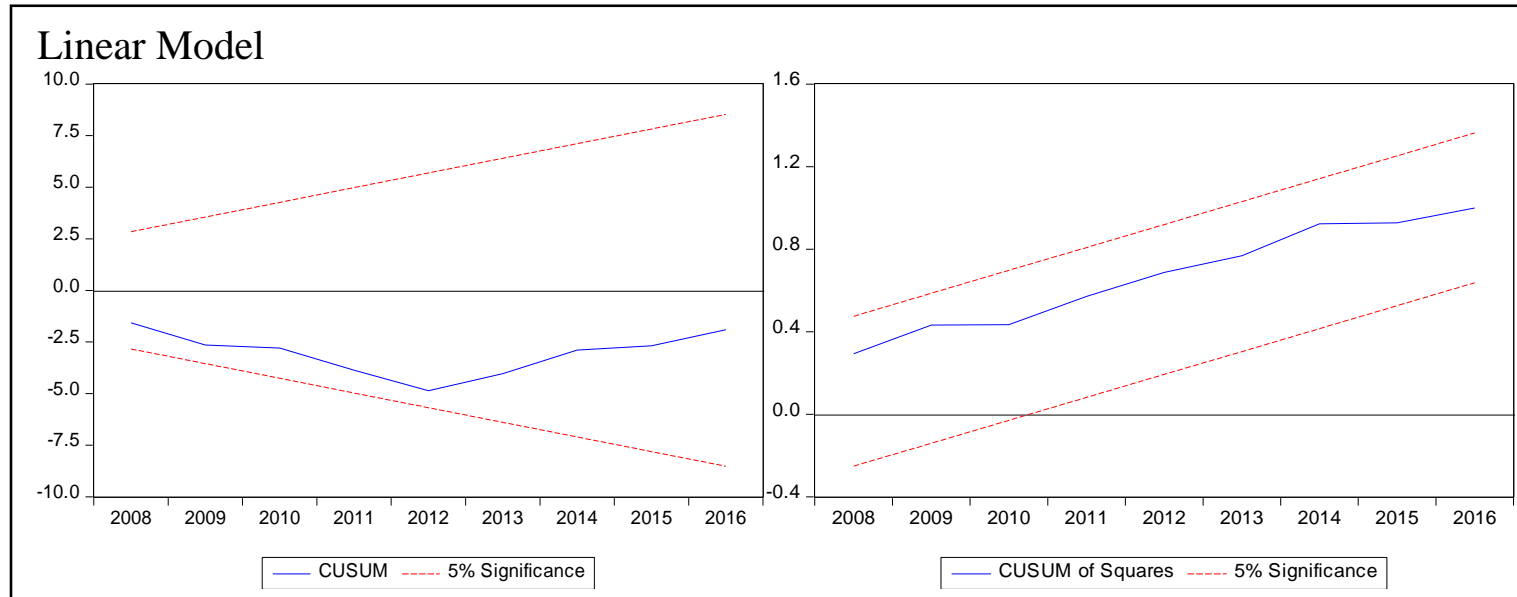

Non-Linear Model
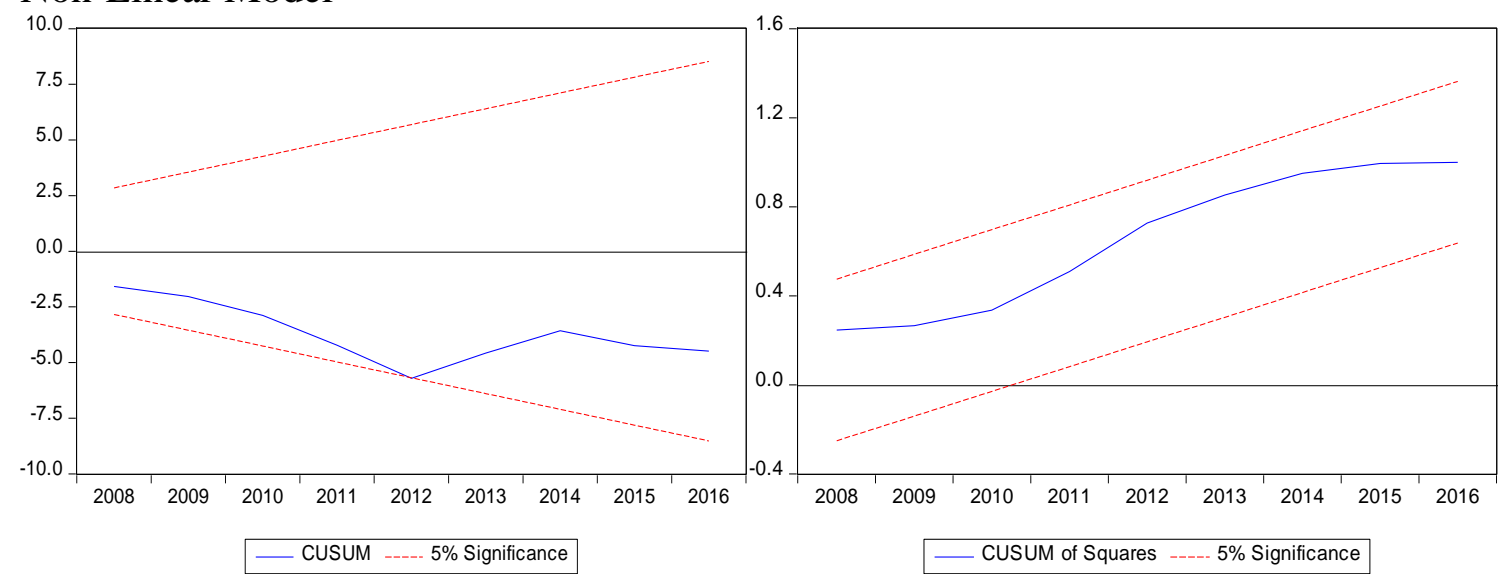

Figure-2: CUSUM \& CUSUM SQUARED 


\section{Carbon Emissions Function}
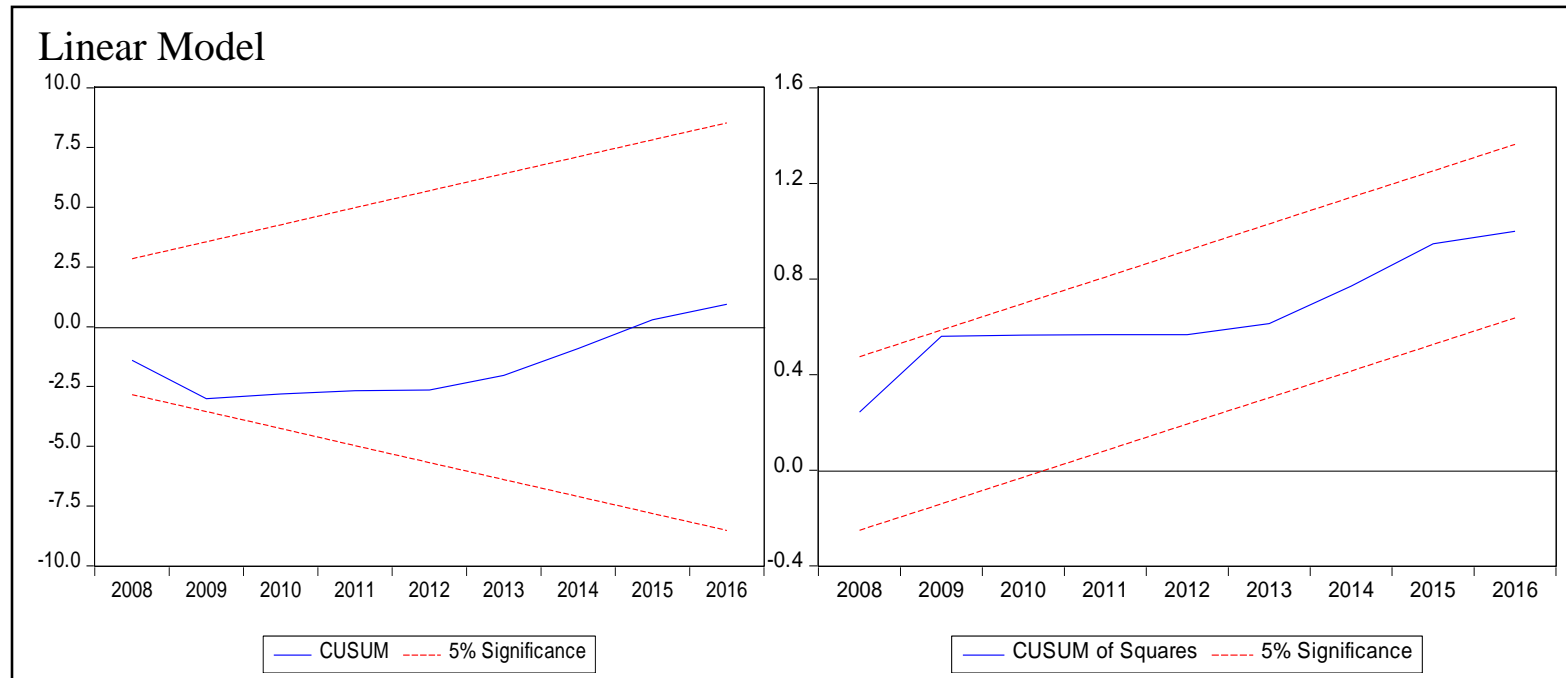

Non-Linear Model
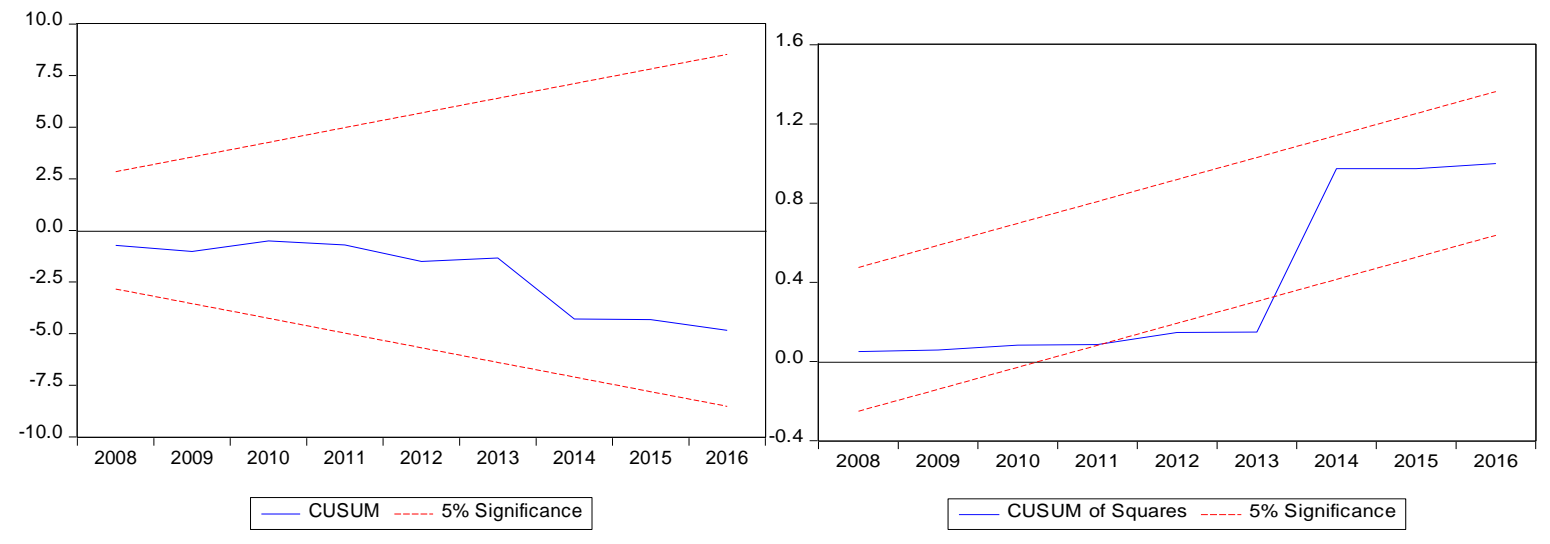

\section{Figure-3: CUSUM \& CUSUMsq}

The results presented in Figure-2 for energy demand function clearly suggests that estimates are reliable in the short run as well as long run. This can be inferred from the fact that the critical bounds of both CUSUM and CUSUMsq remain in the boundaries at 5\% level of significance. For $\mathrm{CO}_{2}$ emissions function, they remain within the bounds for the linear model but in the nonlinear model, CUSUMsq exceeds the critical bounds which indicate a lack of statistical significance to provide reliability to the nonlinear estimates. A noteworthy implication of these 
results is that there is consistency between $\mathrm{CO}_{2}$ emissions and its contributing factors, which is a cause of concern due to inconsiderate environment policy. Furthermore, to confirm whether the short-run and long-run estimates are reliable, we have also applied the Chow Forecast test. The findings are presented in Table-6. The empirical results accept the null hypothesis, which confirms the reliability and consistency of estimates.

\section{Table-6: Chow Test Analysis}

\begin{tabular}{|l|c|c|}
\hline & Test Stat. & P-Value \\
\hline F-stat. & 0.2774 & 0.7596 \\
\hline Likelihood-ratio & 0.7515 & 0.6868 \\
\hline
\end{tabular}

\subsection{VECM Granger Causality Test}

We apply the VECM Granger causality approach to analyse the direction of causality between the variables. The novelty of the approach is that it accounts for the structural break while analysing the long-run and short-run association between variables. Table-7 summarises the test results on energy demand function. There is evidence of causality running from natural resources to energy consumption in the long run. There is bi-directional causality between the consumption of energy and growth of the economy. However, there was only unidirectional causality from prices of oil to the consumption of energy. There was also feedback effects or bidirectional causality between education and consumption of energy. A bidirectional causal relationship is found be exist between natural resource abundance and energy consumption in the short-run. The feedback or bidirectional causality was also found between the growth of economy and consumption of energy, whereas the education only showed unidirectional causality with energy consumption running from former to the later. Oil prices Granger causes education. There is also evidence of unidirectional causality from natural resources and energy consumption to oil prices. 
The long-run causality analysis on carbon emissions function (Table-8) showed a bidirectional association and hence the presence of feedback nexus between natural resource abundance and carbon emissions. There is also a bidirectional causal association between natural resources and consumption of energy. Consumption of energy and emissions also showed bidirectional causality. The Granger causality also prevailed from economic growth to the consumption of energy, natural resource abundance and carbon emissions, whereas the unidirectional causal association ran from prices of oil to consumption of energy, natural resources abundance and carbon emissions. Consumption of energy, the abundance of natural resources and carbon emissions are found to be a Granger cause of education. A feedback effect is evident between natural resources and carbon emissions in the short-run. Growth of economy and education Granger causes emissions of $\mathrm{CO}_{2}$. It also showed that the consumption of energy is a Granger cause of emissions, however, the growth of the economy is also Granger caused by the consumption of energy which is intuitive. A unidirectional causality prevailed running form education, natural resources and carbon emissions to oil prices. Education showed a causal influence on the consumption of energy. 
Table-7: Analysis of VECM-Granger Causality (Energy Demand Function)

\begin{tabular}{|c|c|c|c|c|c|c|c|c|c|}
\hline \multirow[t]{2}{*}{ Variable } & \multicolumn{6}{|l|}{ Short-Run } & \multirow{2}{*}{\begin{tabular}{|c|} 
Long Run \\
$E C M_{t-1}$
\end{tabular}} & \multicolumn{2}{|c|}{ Stability Analysis } \\
\hline & $\sum \Delta \ln E C_{t-1}$ & $\sum \Delta \ln R_{t-1}$ & $\sum \Delta \ln Y_{t-1}$ & $\sum \Delta \ln O_{t-1}$ & $\sum \Delta \ln E_{t-1}$ & Break Year & & CUSUM & CUSUMsq \\
\hline$\Delta \ln E C_{t}$ & $\ldots$ & $\begin{array}{c}8.8981 * * \\
{[0.0297]}\end{array}$ & $\begin{array}{c}12.5715^{*} \\
{[0.0000]}\end{array}$ & $\begin{array}{c}2.4561 \\
{[0.1045]}\end{array}$ & $\begin{array}{c}3.3923^{* *} \\
{[0.0408]}\end{array}$ & 2007 & $\begin{array}{l}-0.3546^{*} \\
{[-2.8286]}\end{array}$ & Stable & Stable \\
\hline$\Delta \ln R_{t}$ & $\begin{array}{c}4.6857 * * \\
{[0.0176]}\end{array}$ & $\ldots$ & $\begin{array}{c}1.5101 \\
{[0.2303]}\end{array}$ & $\begin{array}{l}12.3091 \\
{[0.0000]}\end{array}$ & $\begin{array}{c}2.7845 * * * \\
{[0.0789]}\end{array}$ & 1999 & $\ldots$ & Stable & Stable \\
\hline$\Delta \ln Y_{t}$ & $\begin{array}{l}9.5341 * \\
{[0.0007]}\end{array}$ & $\begin{array}{c}1.0066 \\
{[0.3783]}\end{array}$ & $\ldots$ & $\begin{array}{c}0.9745 \\
{[0.3898]}\end{array}$ & $\begin{array}{c}1.4492 \\
{[0.2518]}\end{array}$ & 2007 & $\ldots$ & Stable & Stable \\
\hline$\Delta \ln O_{t}$ & $\begin{array}{c}2.8706 * * * \\
{[0.0738]}\end{array}$ & $\begin{array}{c}22.1700 * \\
{[0.0000]}\end{array}$ & $\begin{array}{c}0.9917 \\
{[0.3836]}\end{array}$ & $\ldots$ & $\begin{array}{c}1.9273 \\
{[0.1643]}\end{array}$ & 2003 & $\ldots$ & Stable & Stable \\
\hline$\Delta \ln E_{t}$ & $\begin{array}{c}2.3489 \\
{[0.1140]}\end{array}$ & $\begin{array}{c}3.7234 * * \\
{[0.0367]}\end{array}$ & $\begin{array}{c}1.1886 \\
{[0.3195]}\end{array}$ & $\begin{array}{l}8.8472 * \\
{[0.0011]}\end{array}$ & $\ldots$ & 2001 & $\begin{array}{c}-0.1705 * * \\
{[-2.0866]}\end{array}$ & Stable & Stable \\
\hline & $\sum \Delta \ln E C_{t-1}$ & $\begin{array}{l}\sum \Delta \ln R_{t-1} \\
\sum \Delta \ln R_{t-1}^{2}\end{array}$ & $\sum \Delta \ln Y_{t-1}$ & $\sum \Delta \ln O_{t-1}$ & $\sum \Delta \ln E_{t-1}$ & Break Year & $E C M_{t-1}$ & CUSUM & CUSUMsq \\
\hline$\Delta \ln E C_{t}$ & $\ldots$ & $\begin{array}{c}3.6388 * * \\
{[0.0634]}\end{array}$ & $\begin{array}{c}11.8900 * \\
{[0.0000]}\end{array}$ & $\begin{array}{c}1.9207 \\
{[0.1123]}\end{array}$ & $\begin{array}{c}4.0657 * * \\
{[0.0401]}\end{array}$ & 2007 & $\begin{array}{l}-0.2370^{*} \\
{[-2.8708]}\end{array}$ & Stable & Stable \\
\hline $\begin{array}{l}\Delta \ln R_{t} \\
\Delta \ln R_{t-1}^{2}\end{array}$ & $\begin{array}{l}4.7956 * * \\
{[0.0155]}\end{array}$ & $\ldots$ & $\begin{array}{c}1.4134 \\
{[0.2406]}\end{array}$ & $\begin{array}{l}12.9001 \\
{[0.0000]}\end{array}$ & $\begin{array}{c}3.0845 * * * \\
{[0.0611]}\end{array}$ & 1999 & $\ldots$ & Stable & Stable \\
\hline$\Delta \ln Y_{t}$ & $\begin{array}{l}\text { Q0.0301* } \\
{[0.0001]}\end{array}$ & $\begin{array}{c}1.1266 \\
{[0.3613]}\end{array}$ & $\ldots$ & $\begin{array}{c}1.0904 \\
{[0.3785]}\end{array}$ & $\begin{array}{c}1.3972 \\
{[0.2601]}\end{array}$ & 2007 & $\cdots$ & Stable & Stable \\
\hline
\end{tabular}




\begin{tabular}{|c|c|c|c|c|c|c|c|c|c|}
\hline$\Delta \ln O_{t}$ & $\begin{array}{c}3.0716^{* * * *} \\
{[0.0608]}\end{array}$ & $\begin{array}{c}20.6717 * \\
{[0.0000]}\end{array}$ & $\begin{array}{c}1.0907 \\
{[0.3703]}\end{array}$ & $\ldots$ & $\begin{array}{c}1.8903 \\
{[0.1704]}\end{array}$ & 2003 & ... & Stable & Stable \\
\hline$\Delta \ln E_{t}$ & $\begin{array}{c}2.3219 \\
{[0.1176]}\end{array}$ & $\begin{array}{c}3.9204 * * \\
{[0.0354]}\end{array}$ & $\begin{array}{c}1.1282 \\
{[0.3315]}\end{array}$ & $\begin{array}{l}8.8040^{*} \\
{[0.0013]}\end{array}$ & $\ldots$ & 2001 & $\begin{array}{c}-0.1723 * * \\
{[-2.0876]}\end{array}$ & Stable & Stable \\
\hline
\end{tabular}

Table-8: Analysis of VECM Granger Causality (Carbon Emissions Function)

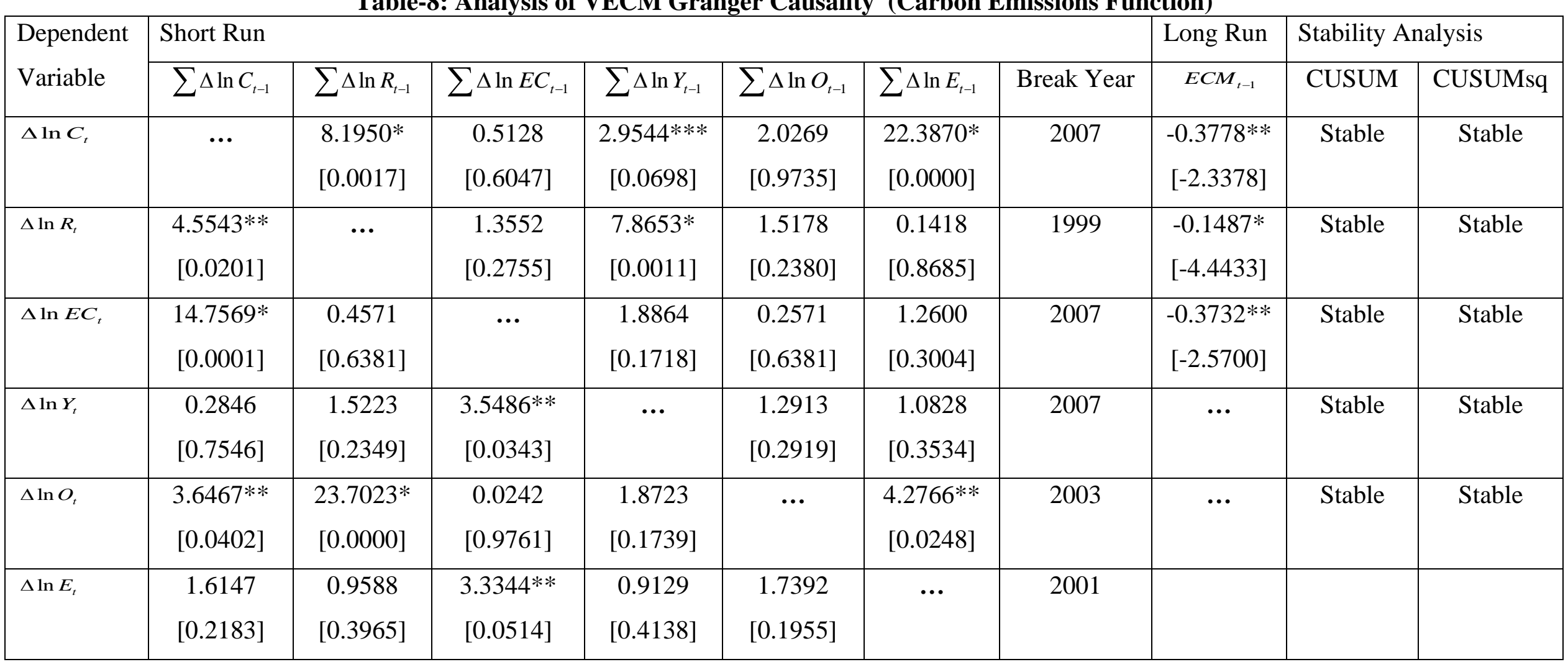




\begin{tabular}{|c|c|c|c|c|c|c|c|c|c|c|}
\hline & $\sum \Delta \ln C_{t-1}$ & $\begin{array}{l}\sum \Delta \ln R_{t-1} \\
\sum \Delta \ln R_{t-1}^{2}\end{array}$ & $\sum \Delta \ln E C_{t-1}$ & $\sum \Delta \ln Y_{t-1}$ & $\sum \Delta \ln O_{t-1}$ & $\sum \Delta \ln E_{t-1}$ & Break Year & $E C M_{t-1}$ & CUSUM & CUSUMsq \\
\hline$\Delta \ln C_{t}$ & $\ldots$ & $\begin{array}{l}8.2015^{*} \\
{[0.0015]}\end{array}$ & $\begin{array}{c}0.6585 \\
{[0.5867]}\end{array}$ & $\begin{array}{c}3.0987 * * * \\
{[0.0652]}\end{array}$ & $\begin{array}{c}1.9768 \\
{[0.9756]}\end{array}$ & $\begin{array}{l}19.9087^{*} \\
{[0.0000]}\end{array}$ & 2007 & $\begin{array}{c}-0.3870 * * \\
{[-2.5789]}\end{array}$ & Stable & Stable \\
\hline $\begin{array}{l}\Delta \ln R_{t} \\
\Delta \ln R_{t-1}^{2}\end{array}$ & $\begin{array}{c}4.2567 * * \\
{[0.0311]}\end{array}$ & $\ldots$ & $\begin{array}{c}1.2345 \\
{[0.2976]}\end{array}$ & $\begin{array}{c}3.0987 * * * \\
{[0.0617]}\end{array}$ & $\begin{array}{c}1.4152 \\
{[0.2401]}\end{array}$ & $\begin{array}{c}0.2134 \\
{[0.8567]}\end{array}$ & 1999 & $\begin{array}{l}0.1678^{*} \\
{[3.0987]}\end{array}$ & Stable & Stable \\
\hline$\Delta \ln E C_{t}$ & $\begin{array}{l}12.8901^{*} \\
{[0.0008]}\end{array}$ & $\begin{array}{c}0.3546 \\
{[0.6457]}\end{array}$ & $\ldots$ & $\begin{array}{c}2.0987 \\
{[0.1615]}\end{array}$ & $\begin{array}{c}0.2345 \\
{[0.6475]}\end{array}$ & $\begin{array}{c}1.1019 \\
{[0.3345]}\end{array}$ & 2007 & $\begin{array}{c}-0.3456^{*} \\
{[-3.0789]}\end{array}$ & Stable & Stable \\
\hline$\Delta \ln Y_{t}$ & $\begin{array}{c}0.3019 \\
{[0.7451]}\end{array}$ & $\begin{array}{c}1.4765 \\
{[0.2424]}\end{array}$ & $\begin{array}{c}4.0879 * * \\
{[0.0314]}\end{array}$ & $\ldots$ & $\begin{array}{c}1.1717 \\
{[0.3245]}\end{array}$ & $\begin{array}{c}0.9567 \\
{[0.3645]}\end{array}$ & 2007 & $\ldots$ & Stable & Stable \\
\hline$\Delta \ln O_{t}$ & $\begin{array}{c}4.0567 * * \\
{[0.0329]}\end{array}$ & $\begin{array}{c}20.1980^{*} \\
{[0.0000]}\end{array}$ & $\begin{array}{c}0.0345 \\
{[0.9678]}\end{array}$ & $\begin{array}{c}1.7765 \\
{[0.1978]}\end{array}$ & $\cdots$ & $\begin{array}{c}5.0987 * * \\
{[0.0237]}\end{array}$ & 2003 & $\ldots$ & Stable & Stable \\
\hline$\Delta \ln E_{t}$ & $\begin{array}{c}1.7657 \\
{[0.1978]}\end{array}$ & $\begin{array}{c}1.0987 \\
{[0.3819]}\end{array}$ & $\begin{array}{c}4.0789 * * \\
{[0.0434]}\end{array}$ & $\begin{array}{c}0.8567 \\
{[04567]}\end{array}$ & $\begin{array}{c}1.6565 \\
{[0.2012]}\end{array}$ & $\ldots$ & 2001 & $\ldots$ & Stable & Stable \\
\hline
\end{tabular}




\section{Conclusion and Policy Implications}

The withdrawal of the United States from the non-binding Paris Agreement is an ordeal for the world's largest economy as well as for the global economy, indisputably it has a number of negative political-economic and ecological repercussions. While acknowledging this misfortune for the world, this study is an endeavour to underscore and reflect on some of the underlying contributing factors to energy consumption and carbon emissions in the US, particularly in a regime of steady economic growth and low oil prices where the US herself is a major contributor. In this nexus, we also consider the role of education as a basis for some degree of optimism.

Our empirical findings indicate a strong presence of long as well as short-run associations among the underlying variables. Specifically, they suggest that the abundance of resources and economic growth of the US economy accelerate the consumption of energy and deteriorate the quality of the environment by significantly increasing the emissions of $\mathrm{CO}_{2}$. Thus, natural resources abundance leads to a carbon curse in the United States. The negative effect of oil prices is also noted for energy consumption and carbon emissions. Energy consumption also significantly contributes to greater emissions of $\mathrm{CO}_{2}$. Causality analysis underscores the validity of the resources led-energy hypothesis and the presence of a feedback effect between natural resource abundance and $\mathrm{CO}_{2}$ emissions. As a silver lining to this dark cloud, education has shown to be a factor which reduces the intensity of energy consumption and improves environmental quality by lowering $\mathrm{CO}_{2}$ emissions. Indeed, our result is in line with various studies quoted in the introduction, which showed that education foster environmental consciousness, (Meyer 2015, Chankrajang and Muttarak 2017). Furthermore, Grimaud and Tournemaine (2007) bring evidence that if education is used as a channel for the environment policy, it can promote eco-friendly growth. In other words, National Environmental Education Advisory Council, 1996 has born fruits, as US public opinion is in 
favour of taking measures and having behaviour that protects the environment. In addition, several big American companies, states as well as big cities like New York, have decided to take measure in accordance with the COP 21 agreements. All this corroborate our results. Again, these features of the American society that comes from education are a sign that despite the US withdrawal, education can be used as a powerful weapon to fight global warming and curve $\mathrm{CO}_{2}$ emissions in the US and in other big emitter-countries.Considering the fact that the United States is the second-largest consumer of energy, and therefore is a major emitter of greenhouse gases, these findings for the United States should have significant global economic and ecological implications for the U.S. and the World. In the context of the contemporary macroeconomic outlook of the US economy and the focus of the current administration on economic growth, infrastructure and jobs, there are significant environmental and ecological externalities which cannot be overlooked. A myopic and ecologically discourteous growth agenda will not only limit the U.S. ability to tap into the lucrative low-carbon business opportunities in the world but will cause damage to the global environment. Particularly, as oil production in the U.S. is at a historically high level due to the shale oil revolution, there is a real danger that the abundance of oil and the resulting low prices will boost both oil consumption and $\mathrm{CO}_{2}$ emissions.

Although the silver lining in this study is that education lowers energy intensity and improves environmental quality, where this continues to give hopes after the U.S. withdrawal from the Paris Agreement (COP-21), it also places bigger responsibilities on the shoulders of those aware of the ecological issues in order to educate the American society. Concomitantly, the appreciable stance in G-20 by France and the solidarity by the EU and China on the Paris Agreement, as well as the state-level efforts in the U.S. to compensate for the federal withdrawal can be remotivated by the conclusions of this study. The public and businesses' appetites for more ecologically friendly economic policies, which can create jobs and 
sustainable growth, are perhaps the most appropriate choice for the US Administration to take than attempts to revive the economy on high carbon technologies of the past. Conceivably, a society with more consciousness of ecological challenges may steer the US administration's policies towards a more sustainable and cleaner path.

\section{References}

Alam, M. Q., Shabbir, A. M. and Ahsan J. S., 2016. Oil demand and price elasticity of energy consumption in the GCC countries: A panel cointegration analysis. Busin. and Eco.Horizons, 12 (2), 63-74.

Anderson, A., 2010. Combating Climate Change Through Quality Educations, Global Economy and Development at Brookings, Global Views, Policy Brief 2010-03, 1-16.

Arora, V. and Shi, S., 2016. Energy consumption and economic growth in the United States. Appl. Eco., 48 (39), 3763-3773.

Asali, M., 2011. Income and price elasticities and oil-saving technological changes in ARDL models of demand for oil in G7 and BRIC. OPEC Energy Rev., 189-219.

Ayalon, O., Brody, S., Shechter, M., 2014. Household waste generation, recycling and prevention. Org. for Eco. Co-op. and Dev., pp. 219-245.

Badeeb, R. A., Lean, H. H. and Smyth, R., 2016. Oil curse and finance-growth nexus in Malaysia: The role of investment. Ene. Eco., 57, 154-165.

Balsalobre-Lorente, D. Shahbaz, M. Roubaud, D. Farhani, S., 2018, How economic growth, renewable electricity and natural resources contribute to $\mathrm{CO} 2$ emissions? Ene. Pol., 113, 356-367.

Barić, D., Zovak, G. and Periša, M., 2013. Effects of eco-drive education on the reduction of fuel consumption and $\mathrm{CO}_{2}$ emissions. Promet - Traffic \& Transp., 25, 265-272.

Bekhet, H. A. Yusop, N. Y. M., 2009. Assessing the relationship between oil prices, energy consumption and macroeconomic performance in Malaysia: co-integration and vector error correction model (VECM) approach. Intern. Busin Res., 2, 152-175.

Caldara, D., Cavallo, M. and Iacoviello, M., 2017. Oil price elasticities and oil price fluctuations. International Finance Discussion Papers 1173.

Chai, J., Zhou, Y., Liang, T., Xing, L. and Lai, K. K., 2016. Impact of international oil price on energy conservation and emission reduction in China. Sustainability, 8, 1-17.

Chankrajang, T. and Muttarak, R., 2017, Green returns to education: Does schooling contribute to pro-environmental behaviours? Evidence from Thailand. Ecol. Econ., 131, 434-48.

Chiu Y-B., 2017. Carbon dioxide, income and energy: evidence from a non-linear model. Ener Econ., $61,279-88$.

Crippa, M., Oreggioni, G., Guizzardi, D., Muntean, M., Schaaf, E., Lo Vullo, E., Solazzo, E., Monforti-Ferrario, F., Olivier, J.G.J., Vignati, E., Fossil CO2 and GHG emissions of all world countries - 2019 Report, EUR 29849 EN, Publications Office of the European Union, Luxembourg, 2019, ISBN 978-92-76-11100-9, doi:10.2760/687800, JRC117610.

Darrat, A. F. and Gilley, O. W., 1996. US oil consumption, oil prices, and the macroeconomy. Empir. Econ., 21, 317-334.

Dees, S., Karadeloglou, P., Kaufmann, R. K. and Sanchez, M., 2007. Modelling the world oil market: assessment of a quarterly econometric model. Ene. Pol., 35, 178-191. 
Dogan, E. and Turkekul, B., 2016. $\mathrm{CO}_{2}$ emissions, real output, energy consumption, trade, urbanization and financial development: testing the EKC hypothesis for the USA. Envir. Sc. and Pol Res., 23, 1203-1213.

Easley, J., 2017. Trump cements 'America First' doctrine with Paris withdrawal. The Hill, available at [http://thehill.com/homenews/administration/336014-trump-cements-america-first-doctrinewith-paris-withdrawal] accessed on 30th July 2017.

Ek, K. and Soderholm, P., 2008. Norms and economic motivation in the Swedish green electricity market. Ecol. Econ. 68 (1-2), 169-182.

Fang, Z. and Wolski, M., 2017. Human capital, energy and economic growth in China - Evidence from multivariate nonlinear Granger causality. Europ. Invest. Bank, Luxembourg.

Frank, M. W., 2009. Inequality and growth in the United States: Evidence from a new state-level panel of income inequality measure. Econ. Inquiry, 47, 55-68.

Frank, M. W., 2017. Annual State-Level Measures of Human Capital Attainment, 1940-2015: available at http://www.shsu.edu/eco_mwf/inequality.html

Freire, P. , 1970, Pedagogy of the Oppressed, Penguin.

Friedrichs, J. Inderwildi, O. R., 2013, The carbon curse: Are fuel rich countries doomed to high CO2 intensities? Ene. Pol., 62, 1356-1365.

Galston, W. A., 2017. Paris agreement enjoys more support than Donald Trump. Brookings, Available at [https://www.brookings.edu/blog/fixgov/2017/05/31/paris-agreement-enjoys-more-supportthan-trump/] accessed on $12^{\text {th }}$ August 2017.

Grimaud, A. and Tournemaine, F., 2007, Why can an environmental policy tax promote growth through the channel of education? Ecol. Econ., 62, 27-36.

Greene, D. L., 1986. Driver Energy Conservation Awareness Training. Review and Recommendations for a National Program. Oak Ridge National Lab, TN, USA.

Gross, S., 2017. Far from the White House, the energy industry remains focused on climate, Brookings, available at [https://www.brookings.edu/blog/planetpolicy/2017/03/14/far-from-thewhite-house-the-energy-industry-remains-focused-on-climate/] accessed on $12^{\text {th }}$ August 2017.

Hamilton, J. D., 2009. Causes and consequences of the oil shock of 2007-08. Brookings Pap. on Econ. Activity, 1, 215-283.

Helman, C., 2017. OPEC tries to play it cool, but oil markets are in shock over U.S. supply, available at [https://www.forbes.com/sites/christopherhelman/2017/05/25/opec-shock-cant-fight-thefrackers/\#48e9ebff3e93] accessed on $3^{\text {rd }}$ August 2017.

Hsiao-Ping, C. and Tsangyao, C., 2012. Nuclear energy consumption, oil consumption and economic growth in G-6 countries: Bootstrap panel causality test. Ene. Pol., 48, 762-769.

Hultman, N., 2017. The galvanized world response to Trump's Paris Agreement decision, available at [https://www.brookings.edu/blog/planetpolicy/2017/06/07/the-galvanized-world-response-totrumps-paris-agreement-decision/] accessed on 12 $2^{\text {th }}$ August 2017.

Husain, A. M., Arezki, R., Breuer, P., Haksar, V., Helbling, T., Medas, P. and Sommer, M., 2015. Global implications of lower oil prices. IMF Staff Discussion Note, SDN/15/15.

IEA., 2017 Energy-related carbon dioxide emissions worldwide from 1975 to 2016 (in gigatonnes), Available from [https://www.statista.com/statistics/526002/energy-related-carbon-dioxideemissions-worldwide/] Accessed at 31 July, 2017.

Ilesanmi, K. D. and Tiwari, D. D., 2017. Energy consumption, human capital investment and economic growth in South Africa: a vector error correction model analysis. OPEC Ener. Rev., 41, 55-70.

Intergovernmental Panel on Climate Change, Climate Change, 2014-Impacts, Adaptation and Vulnerability: Regional Aspects. Cambridge University Press. 
Jamil, F. and Ahmad, E., 2010. The relationship between electricity consumption, electricity prices and GDP in Pakistan. Energy Policy, 38, 6016-6025.

Kharas. H., 2016. Climate change, fertility and girls' education, Further Development, Bookings, available at [https://www.brookings.edu/blog/future-development/2016/02/16/climate-changefertility-and-girls-education/] accessed at $2^{\text {nd }}$ August 2017.

Kilian, L., 2008a. The economic effects of energy price shocks. J. of Econ. Literature, 46, 871-909.

Kilian, L., 2008b. Exogenous oil supply shocks: How big are they and how much do they matter for the U.S. economy? Rev. of Econ. and Stat., 90, 216-240.

Kilian, L., Rebucci, A. and Spatafora, N., 2009. Oil shocks and external balances. J. of Inter. Econ., 77, 181-94.

Leiserowitz, A., Maibach, E., Roser-Renouf, C., Rosenthal, S. and Cutler, M., 2016. Politics \& Global Warming, November 2016. Yale University and George Mason University. New Haven, CT: Yale Program on Climate Change Communication.

Liew, V. K. S., 2004. Which lag length selection criteria should we employ? Econ. Bul., 33, 1-9.

Lipton, E. and Meier, B., 2017. Under Trump, Coal Mining Gets New Life on U.S. Lands, New York Times, $6^{\text {th }}$ August 2017.

Mahalik, M. K., Suresh, B. M., Nanthakumar, L. and Shahbaz, M., 2017. Does financial development intensify energy consumption in Saudi Arabia? Renew. and Sust. Energy Rev., 75, 1022-1034.

Mazraati, M. and Shelbi, H., 2011. Impact of alternative fuels and advanced technology vehicles on oil demand in the United States up to 2030. OPEC Energy Review, 70-89.

Menyah, K. and Wolde-Rufael, Y., 2010. CO2 emissions, nuclear energy, renewable energy and economic growth in the US. Ene. Pol., 38, 2911-2915.

Miller, J., 2013. Which government policies and other factors have reduced U.S. carbon emissions? The Energy Collective, available at [http://www.theenergycollective.com/jemiller_ep/211171/government-policies-and-otherfactors-have-reduced-us-carbon-emissions] accessed on $13^{\text {th }}$ August 2017.

Moony, C., 2017. Trump's reasons for leaving the Paris climate agreement just don't add up, the Washington Post, available at [https://www.washingtonpost.com/news/energyenvironment/wp/2017/06/01/trumps-reasons-for-leaving-the-paris-climate-agreement-just-dontadd-up/?utm_term=.1caf9a64a363] accessed on 12 ${ }^{\text {th }}$ August 2017.

Moosa, I. A., 1998. Long-run and short-run demand for oil by developing countries: an empirical analysis. OPEC Review: Ener. Econ. \& Related Issues, 22, 1-12.

Morgan, J., 2016. Paris COP 21: Power that Speaks the Truth? Globalization, 13, 943-951.

National Environmental Education Advisory Council, 1996, Report assessing environmental education in the United States and the implementation of the national environmental education act of 1990.

Pablo-Romero, M. P. and Jesus, J. D., 2016. Energy economic and energy consumption: The energyenvironmental Kuznets curve for Latin American and the Caribbean. Ren. and Sust. Ener. Rev., 60, 1343-1350.

Reuters, 2017. U.N. estimates U.S. climate move could add 0.3-degree temperature rise, available at [http://www.reuters.com/article/uk-usa-climatechange-un-idUKKBN18T13U $\}$ accessed on $12^{\text {th }}$ August 2017.

Roberts, T., 2017. Trump dumps Paris: Now what? Available at [https://www.brookings.edu/blog/planetpolicy/2017/06/01/trump-dumps-paris-now-what/] accessed on $12^{\text {th }}$ August 2017.

Saha, D. and Muro, M., 2017. Clean energy's shifting reality: Venture capital recedes, but what's next? Available at [https://www.brookings.edu/blog/the-avenue/2017/05/30/clean-energyventure-capital/] accssed on $12^{\text {th }}$ August 2017. 
Salim, R., Yao, Y. and Chen, G., 2017. Does human capital matter for energy consumption in China? Energy Economics, forthcoming https://doi.org/10.1016/j.eneco.2017.05.016

Shahbaz, M. and Lean, H. H. (2012). Does financial development increase energy consumption? The role of industrialization and urbanization in Tunisia. Ene. Pol., 40, 473-479.

Shahbaz, M., Mallick, H., Mahalik, M. K. and Sadorsky, P., 2016. The role of globalization on the recent evolution of energy demand in India: implications for sustainable development. Ener. Econ., 55, 52-68.

Shahbaz, M., Sarwar, S., Chen, W. and Malik, M. N., 2017. Dynamics of electricity consumption, oil price and economic growth: Global perspective. Ener. Pol., 108, 256-270.

Shearer, C., Bistline, J., Inman, M. and Davis, S. J., 2014. The effect of natural gas supply on US renewable energy and CO2 emissions. Envir. Res. Letters, 9, 1-8.

Sinha, P., Schew, W. A., Sawant, A., Kolwaite, K. J. and Strode, S. A., 2010. Greenhouse Gas Emissions from U.S. Institutions of Higher Education. J. of the Air \& Waste Man. Association, 60, 568-573.

Soytas, U., Sari, R., Ewing, B.T., 2007. Energy consumption, income, and carbon emissions in the United States. Ecol. Econ., 62, 482-489.

Statista, (2017). Countries with the highest oil consumption from 2010 to 2016 (in 1,000 barrels per day), available at [https://www.statista.com/statistics/271622/countries-with-the-highest-oilconsumption-in-2012/] accessed on 1st August 2017.

Swigonski, F., 2017. Market Report Shows Record \$1.4 Trillion Global, \$200 Billion U.S. Revenue for Advanced Energy and Highlights Five Trends Shaping the Future, Advanced Energy Prospective, available at [http://blog.aee.net/market-report-shows-record-1.4-trillion-global-200billion-u.s.-revenue-for-advanced-energy-and-highlights-five-trends-shaping-the-future] accessed on $12^{\text {th }}$ August 2017.

Taubiana, L., 2017. Paris comes to Pittsburg, Project Syndicate, available at [https://www.projectsyndicate.org/onpoint/paris-comes-to-pittsburgh-by-laurence-tubiana-201706? barrier=accessreg] accessed on $12^{\text {th }}$ August 2017.

Uddin, M. M. M., 2014. Causal relationship between education, carbon dioxide (CO2) emission and economic growth in Bangladesh. IOSR J. of Hum. and Soc. Sc., 19, 60-67.

Uddin, M. M. M., 2014. Causal relationship between education, carbon dioxide $\left(\mathrm{CO}_{2}\right)$ emission and economic growth in Bangladesh. IOSR J. of Hum. and Soc. Sc., 19, 60-67.

UNESCO, 2017, Climate change education, available at [http://en.unesco.org/themes/educationsustainable-development/cce] accessed on 31st July 2017.

Wengraf, I., 2012. Easy on the gas the effectiveness of eco-driving. RAC Foundation, London, 2012.

Wessells, C.R., Johnston, R.J., Donath, H., 1999. Assessing consumer preferences for ecolabeled seafood: the influence of species, certifier, and household attributes. Am. J. Agric. Econ. 81 (5), 1084-1089.

Wheeler, D. and Hammer, D., 2010. The economics of population policy for carbon emissions reduction in developing countries. Centre for Global Development, Working paper No. 229.

World Bank, 2017. CO2 emissions (metric tons per capita) available at [http://data.worldbank.org/indicator/EN.ATM.CO2E.PC] accessed on 1st August 2017/

Yusoff, N. Y. B. M. and Latif, N. W. B. A., 2013. Measuring the effects of world oil price change on economic growth and energy demand in Malaysia: An ARDL bound testing approach. Inter. J. of Trade, Econ. and Fin., 4, 29-36. 
Appendix

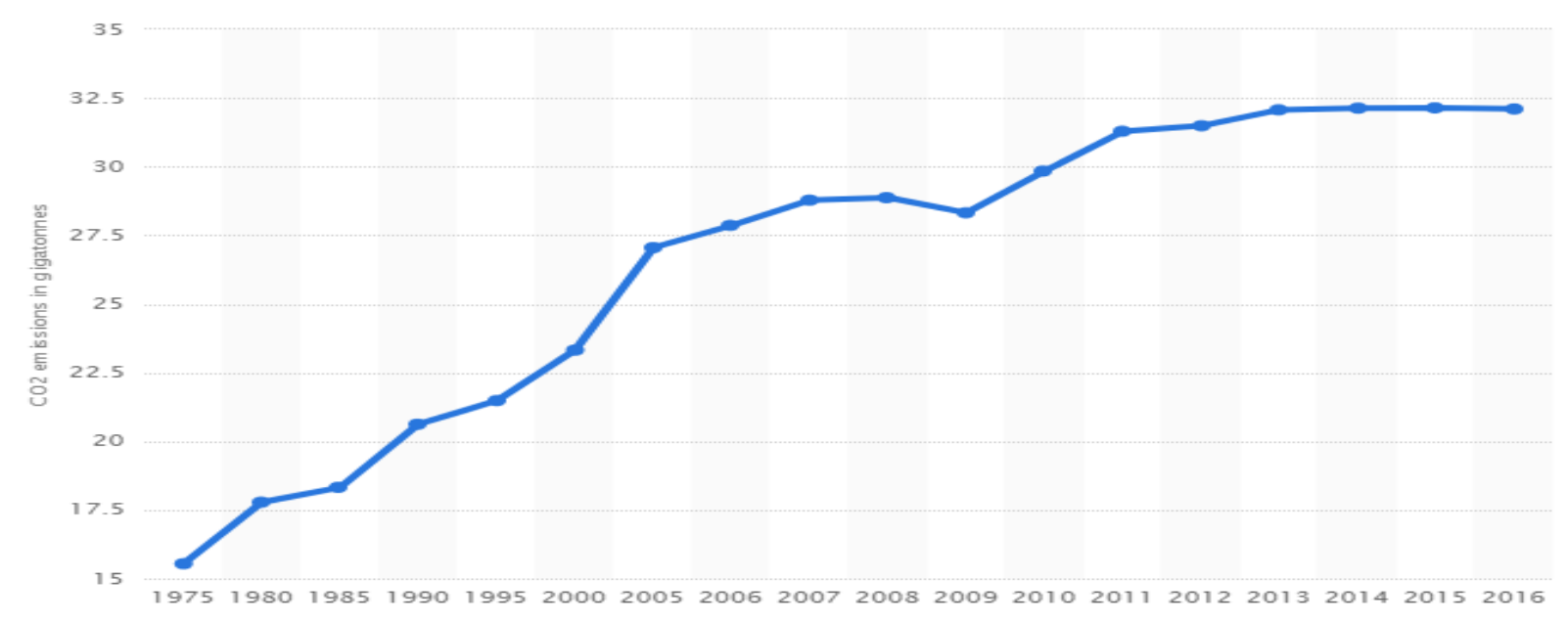

Figure-1: Energy-related Carbon Dioxide Emissions Worldwide from 1975 to 2016:

Source IEA (2017) 